\title{
Geochemistry and eruptive behaviour of the Finca la Nava maar volcano (Campo de Calatrava, south-central Spain)
}

\author{
Matthias Bernhard Lierenfeld ${ }^{1} \cdot$ Hannes B. Mattsson ${ }^{1}$
}

Received: 15 July 2014 / Accepted: 5 March 2015 / Published online: 28 March 2015

(C) Springer-Verlag Berlin Heidelberg 2015

\begin{abstract}
Here we present a detailed investigation into the geochemistry and the excavational/depositional processes involved in the maar-diatreme forming Finca la Nava (FIN) eruption in south-central Spain. Bulk rock compositions of hand-picked juvenile fragments indicate derivation of the FIN magma from a garnet-bearing mantle source, which has subsequently been overprinted in bulk rock samples by incorporation of a combination of spinelbearing peridotites and upper-crustal lithics (i.e. quartzites and slates). The dominating phenocryst assemblage with clinopyroxene, olivine, amphibole and phlogopite points to the classification of the juvenile magma as being olivine melilititic in composition. Ascent through the lithosphere was rapid as indicated by the calculations of settling rates of mantle peridotites $\left(\sim 0.8 \mathrm{~m} \mathrm{~s}^{-1}\right)$. The original magma fragmentation level in the conduit was probably relatively shallow carrying mainly juvenile pyroclasts $(\sim 60 \%)$ intermixed with accidental crustal lithics $(\sim 35 \%)$ and mantle xenoliths $(<5 \%)$ to the surface. The shapes of individual pyroclasts are sub-rounded to rounded and with highly variable vesicularities $(5-45 \%)$. This fact, in combination with abundant fine-grained material in the beginning of the eruption, indicates that both magmatic and phreatomagmatic fragmentation processes may have played important roles in forming the FIN maar. A relatively constant
\end{abstract}

Electronic supplementary material The online version of this article (doi:10.1007/s00531-015-1164-4) contains supplementary material, which is available to authorized users.

Matthias Bernhard Lierenfeld

matthias.lierenfeld@erdw.ethz.ch

Institute of Geochemistry and Petrology, Swiss Federal Institute of Technology (ETH Zürich), Clausiusstrasse 25, 8003 Zurich, Switzerland increase in quartzitic fragments from $\sim 35$ to $<60 \%$ with increasing stratigraphic height in the FIN deposits further indicates that the crater area successively widened during the eruption, which resulted in an increased recycling of quartzitic fragments. This eruption scenario, with the formation of a diatreme at depth, is also consistent with the absence of layers dipping inwards into the crater area.

Keywords Maar volcanism · Diatreme $\cdot$ Melilitite · Fragmentation

\section{Introduction}

Tuff cones and tuff rings are frequently associated with monogenetic maar-diatreme volcanoes, which represent the second most common type of volcanic landform on Earth (Wohletz and Heiken 1992). Maar-forming eruptions penetrate into the surrounding substrate by fragmenting and excavating juvenile material and country rock (Lorenz 1986, 2003; White and Ross 2011; Valentine and White 2012). In principle, the environment of emplacement, equitable for the water availability, has a big influence on the maar formation. It can be distinguished between hard-rock (joint aquifer) and soft-rock (pore aquifer) (Lorenz 2003) as well as some mixed settings (Ross et al. 2011). Hardsubstrate maars are characterized by a cone-shaped diatremes (Ross et al. 2011) consisting of up to $80 \%$ of country rock (Lorenz 1986), whereas soft-substrate maars have a bowl-shaped crater (Auer et al. 2007), and their tephra ring contains individual mineral grains and rock pebbles from the surrounding sediments (Lorenz 2003).

After the eruption that involves numerous individual explosions, the final landform is a rounded crater with a diameter of up to $3 \mathrm{~km}$ (White and Ross 2011) and a depth 
of up to several hundred metres (Lorenz 2007). The crater is underlain by a funnel-shaped diatreme structure that can reach depths of up to $2 \mathrm{~km}$ (White and Ross 2011; Delpit et al. 2014) and that are very similar to those found in kimberlitic systems in terms of diatreme geometry, depth and architecture (Lefebvre and Kurszlaukis 2008; White and Ross 2011). Typically, the surface deposits of maardiatreme volcanoes consist of a bedded tephra ring, which is rich in country rocks (up to 80-90 \%) (Lorenz 1975, 1986; Wohletz and Zimanowski 2000). The tephra rings are typically characterized by steep inner slopes $\left(30^{\circ}-35^{\circ}\right)$ and relatively flat outer slopes $\left(5^{\circ}-15^{\circ}\right)$ (Lorenz 2007). Layers that dip inwards into the crater are frequently missing due to the progressive growth of the diatreme and excavation of the country rock (Lorenz 1986). A progressive change of lithic content in maar volcanoes can be interpreted as a deepening of the fragmentation depth, and more recent studies can explain this by mixing of upward directed debris jets/explosions and downward subsidence occurring simultaneously (Valentine and White 2012; Lefebvre et al. 2013; Graettinger et al. 2014). Other possible processes are for example lateral vent migration (Németh et al. 2001; Ort and Carrasco-Núñez 2009; Jordan et al. 2013; Kurszlaukis and Fulop 2013) and recycling of ejected material (Houghton and Smith 1993; Ross and White 2012; Lefebvre et al. 2013).

For approximately 50 years, two contrasting ideas have been intensely debated to explain maar-diatreme formation. Some researchers have been arguing for explosive interactions with an external water source [i.e. phreatomagmatism (McBirney 1963; Lorenz 1975, 1986; Nixon 1995; White 1996; Kurszlaukis et al. 1998; Wohletz and Zimanowski 2000; Lorenz and Kurszlaukis 2007; Valentine and White 2012)], while some have argued for explosive exsolution of volatiles as a result of rapid decompression [i.e. magmatic fragmentation (Clement 1982; Stoppa 1996; Field and Scott Smith 1998; Sparks et al. 2006; Wilson and Head III 2007; Cas et al. 2008; Mattsson and Tripoli 2011; Berghuijs and Mattsson 2013)]. This latter hypothesis is usually applied to silica-undersaturated, $\mathrm{CO}_{2}$-rich, magma compositions such as kimberlites, carbonatites, melilitites and nephelinites rising quickly from the mantle to the surface (Sparks et al. 2006; Brown et al. 2009; Suiting and Schmincke 2009; Mattsson and Tripoli 2011; Suiting and Schmincke 2012). Furthermore, an often observed phenomenon is the drying out of the eruption due to the decrease in water supply, which leads to a shift of the mode of fragmentation from a phreatomagmatic to a magmatic one (Lorenz 1986; Németh et al. 2001; Geshi et al. 2011).

Here we investigated the geochemistry and eruption behaviour of the olivine nephelinitic Finca la Nava maar volcano in Campo de Calatrava (south-central Spain, Fig. 1). A combination of geochemistry and mineral chemistry is used to infer the source region for the FIN maar in the upper subcontinental lithosphere. Moreover, detailed field studies, stratigraphic logging and systematic collection of bulk rock samples with increasing stratigraphic height are used to infer the growth of a diatreme beneath FIN. Pyroclast morphologies are used to infer fragmentation modes during the eruption, and finally, a growth model for the Finca la Nava maar is proposed.

\section{Geological setting and previous work}

The Finca la Nava maar is located in south-central Spain, around $220 \mathrm{~km}$ south of Madrid, in the Calatrava Volcanic Province (CVP; Fig. 1). Within the CVP, nearly 130 maars can be found covering an area of approximately $4000 \mathrm{~km}^{2}$ [i.e. 60 hard-substrate and 66 soft-substrate maars (MartínSerrano et al. 2009)]. In the soft-substrate maars of the CVP, the eruptions penetrated into poorly consolidated lacustrine Pliocene sediments (predominantly arkosic sands, marls and silts), whereas in the hard-substrate maars they penetrated into the crystalline Palaeozoic basement (slates, limestones and quartzites) (Martín-Serrano et al. 2009). The CVP is situated within the Neogene-present western and central European geological provinces (Villaseca et al. 2010), a typical intracontinental area bordered by small Late Cenozoic basins that are overlying Variscan basement (Cebriá and López-Ruiz 1995; Villaseca et al. 2010). The Late Miocene-Quaternary volcanic rocks crop out in a region that is dominated by Variscan basement rocks and in some parts overlying by Late Cenozoic sediments. The Palaeozoic basement is composed of quartzites from the Armorican facies (lower Ordovician), limestones (upper Ordovician) and slates (Ordovician-Silurian). It is deformed by the Variscan orogeny that led to the development of a series of NW-SE- to W-E-oriented faults (López-Ruiz et al. 1993). In the Late Miocene-Early Quaternary, fluvial and lacustrine sediments were deposited, which lie unconformably over the basement. The sediments were deposited in fault-bounded basins formed in an extensional tectonic period during the Late Miocene (López-Ruiz et al. 1993). The volcanic activity started on the western edge of the CVP in the Late Miocene with the emplacement of melilitites and leucitic foidites at the volcano Morrón de Villamayor (Stoppa et al. 2012). Two separated periods of volcanic activity can be distinguished by $\mathrm{K}-\mathrm{Ar}$ age dating. The first period lasted from 8.7 to $6.4 \mathrm{Ma}$ and was dominated by olivine-leucitic magmas. The second period was dominated by basaltic magmas taking place from 3.7 to 0.7 Ma (Cebriá and López-Ruiz 1995; Ancochea 2004).

The most recent petrogenetic evolution model for the CVP is based on an asthenospheric mantle diapir that triggered 


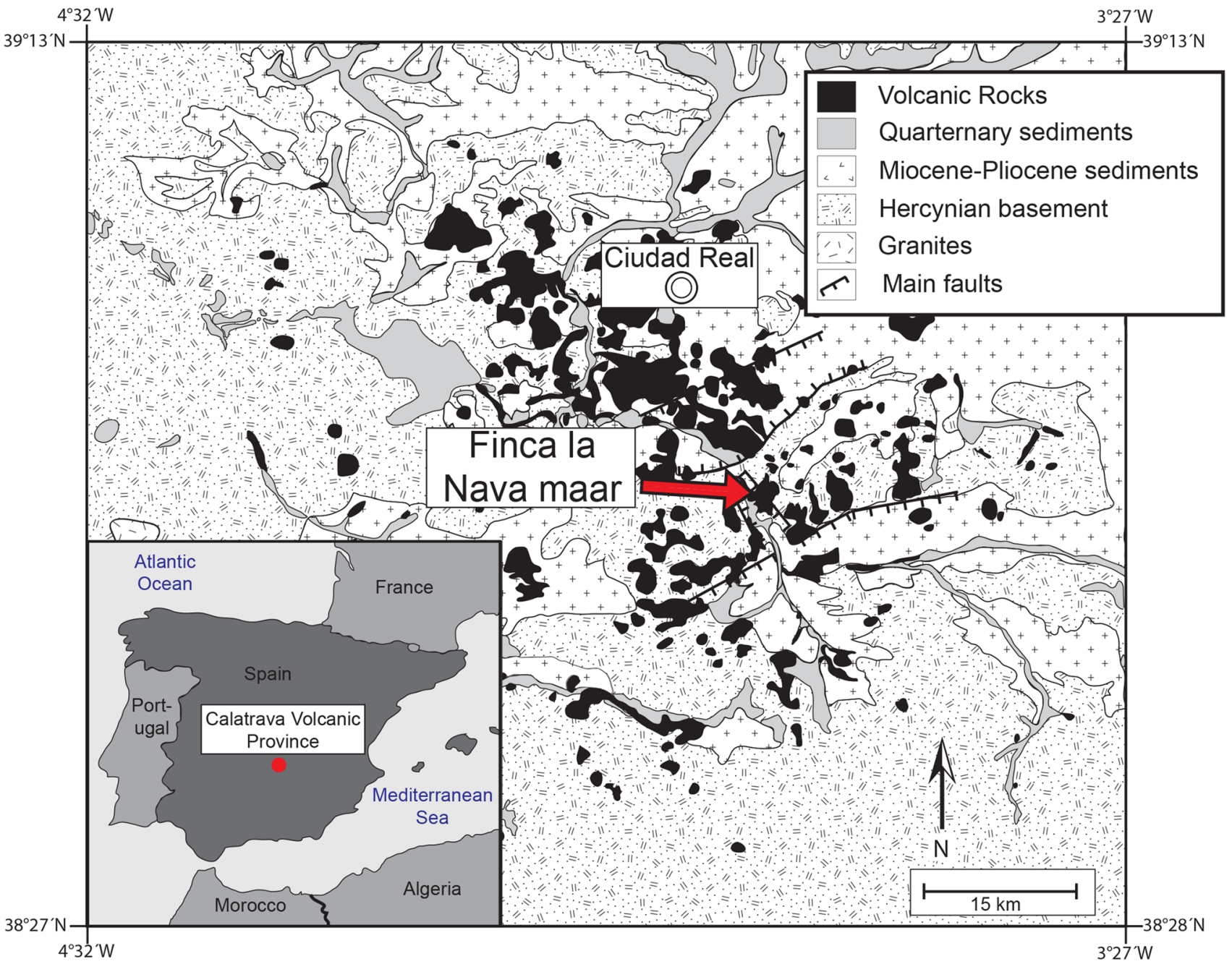

Fig. 1 Idealized geological map modified after Cebriá and López-Ruiz (1996) showing the geographical position of the Finca la Nava maar deposit in the Calatrava Volcanic Province

the magma production in the subcontinental lithosphere. This initiated an extensional period that gave rise to basaltic OIB-like liquids (Cebriá and López-Ruiz 1995). Geochemically, the volcanic rocks in the CVP are divided into four different groups: olivine melilitites (most abundant), olivine nephelinites, alkali olivine basalts and olivine leucitites. Sedimentation in the basins and the magma emplacement was occurring simultaneously with the sequence from young to old: olivine leucitites, olivine melilitites, nephelinites and basalts (Cebriá 1992). In addition to this, Bailey et al. (2005) reported the first findings of primary (magmatic) carbonates/carbonatites within the CVP. These carbonate globules occurred in melilitite glass and also as inclusions in clinopyroxenes and olivines, and in order to explain their observations, the authors proposed that the CVP must be underlain by a phlogopite-carbonate-bearing mantle source. In a more recent publication, Stoppa et al. (2012) also reported the occurrence of carbonatitic lapilli tuffs containing concentric-shelled lapilli in some maar deposits within the CVP (including the Finca la Nava maar).

The prominent round-shaped Finca la Nava maar [for comparison see Fig. 3a, b in Stoppa et al. (2012)] is located approximately $2 \mathrm{~km} \mathrm{NE}$ of the Río Jabalón river. With a mean diameter of $1500 \mathrm{~m}$ and an average surface area of $1.77 \mathrm{~km}^{2}$, it is one of the largest maar structures within the CVP. The FIN maar developed in a hard-substrate environment (Martín-Serrano et al. 2009), and the studied deposit is one of the most prominent outcrops around the crater $\left(38^{\circ} 50.283960 \mathrm{~N}, 3^{\circ} 49.411320 \mathrm{~W}\right)$. Since the time of formation, the crater has infilled with volcaniclastic material and country rock from the collapsing rims. The presentday crater floor lies at $658 \mathrm{~m}$ a.s.l., whereas the outcrop is located approximately $1 \mathrm{~km} \mathrm{NNE}$ of the crater floor at an elevation of $712 \mathrm{~m}$ a.s.l.

The deposit is a tuff ring with its bedding planes dipping flatly (approximately $5^{\circ}$ ) out of the direction of the crater. 
The maar deposits can be divided into a lower and upper outcrop, spatially separated by approximately $150 \mathrm{~m}$ generating a stratigraphic hiatus of around $10 \mathrm{~m}$ covered by scree. They most likely represent a single eruptive sequence as the direction of the bedding planes is identical for both outcrops. The Finca la Nava maar is surrounded by Palaeozoic basement, i.e. massive quartzites and slate. In the direct vicinity of the crater, quartzites are frequently cropping out whereas slates occur rarely. Furthermore, in the broader peripheries, limestone is present in the river beds of the Río Jabalón but no outcrops of limestone have been found close to the FIN crater.

\section{Methods}

The terminology we use follows that of Fisher and Schmincke (1984): juvenile pyroclasts correspond to that material that was fragmented explosively by the eruption of the magma. Due to the monogenetic nature of the FIN maar and the fact that all the juvenile fragments are fluidal, we do not define any accessory clasts from earlier eruptions (Houghton and Smith 1993). Instead, they are exclusively defined as juvenile clasts without any further distinction between "first-cycle" juvenile clasts or "recycled" ones. This does not exclude the existence of accessory and recycled clasts, we just could not distinguish them if they existed (Houghton and Smith 1993). Furthermore, accidental crustal lithics are defined as the country rocks of the Palaeozoic basement together with the mantle xenoliths. The term "bulk rock" refers in our study to all the rock components together with the cementing matrix (for comparison, see the $\mathrm{CaO}$ outliner in the Electronic Appendix).

In the field, the FIN maar deposit was sampled in a detailed and systematic way. As it can be seen in the Electronic Appendix, thirteen stratigraphic sections over the whole height of the two outcrops were logged, and from each log one bulk rock sample was collected in such a way that this bulk rock sample is representative for each sampled stratigraphic layer. To ensure that only the freshest possible material was collected, the outermost $2-10 \mathrm{~cm}$ of each log was removed, then a uniform trench was dug into the outcrop (Fig. 2c), and each layer was sampled (approximately $1-5 \mathrm{~kg}$ ). The grain size distribution was established by sieving the unconsolidated and non-welded tephra. An automated sieve with mesh sizes ranging from 0.063 to $20 \mathrm{~mm}$ was used. Larger grains were measured by hand. The sieved material was checked for composite clasts, which is a mechanical mixture of juvenile and lithic (and/or recycled juvenile) clasts (White and Houghton 2006). When found, these composite clasts were removed but contamination with them cannot be excluded, especially for the finer grain sizes leading to a progressive underestimation of the finer grain sizes. The grain sizes are given in phi values following the expression $\Phi=-\log _{2} d$, where $d$ is the grain diameter in millimetres (Inman 1952). Median grain size $\left(M_{\mathrm{d}} \Phi\right)$, sorting $(\sigma \Phi)$, skewness and kurtosis were calculated with the GradiStat spreadsheet (Blott and Pye 2001). The portion of the juvenile material was determined by hand-picking of the $>4 \mathrm{~mm}$ fraction. For the $2-4 \mathrm{~mm}$ fraction, not the whole suite of material was handpicked but a representative portion to recalculate the portion of juvenile material. The $<2 \mathrm{~mm}$ fractions were not picked due to their small grain sizes.

In order to record compositional variations and changes in magma and country rock fragmentation efficiency over time during the eruption, we conducted analyses of handpicked juvenile material, of one bulk rock sample of each individual layer, as well as of all the representative samples of the main xenolithic components (i.e. quartzites, slates and mantle xenoliths). Approximately half of each bulk rock sample collected in the field (approximately 1-5 kg) was crushed to produce a homogenous powder, which was later used for the bulk rock analysis. As the grain size of the bulk-samples is rather fine, the very largest clasts in each sample were removed in order to not bias the geochemical analyses. From the remaining half of each sample, we hand-picked juvenile material and also the main xenolithic components. The separated components were then milled to a fine-grained powder using an agate mortar. Following this procedure, the rock powders were mixed with lithiumtetraborate $\left(\mathrm{Li}_{2} \mathrm{~B}_{4} \mathrm{O}_{7}\right)$ flux in the ratio of 1:5 and fused at $1200{ }^{\circ} \mathrm{C}$ in $\mathrm{Pt}_{95} \mathrm{Au}_{5}$ crucibles to produce glass pills.

Major elements were analysed by X-ray fluorescence (XRF) spectrometry. An Axios wavelength-dispersive spectrometer of PANalytical was used, and the measurements were carried out at $20-60 \mathrm{kV}$ and $40-100 \mathrm{~mA}$ operating conditions. All measurements are corrected for the loss on ignition (LOI).

The concentration of the trace elements was determined by the laser ablation-induced coupled plasma mass spectrometry (LA-ICP-MS) at a 193-nm argon fluorine (ArF) exciter laser system connected to an ELAN 6100 quadrupole ICP-MS [for details, see Günther et al. (1997)]. Helium acted as carrier gas. A standard reference material (NIST610) was measured for calibration, following the ablation protocol and the data reduction protocol by Longerich et al. (1996). The ablation was performed on pieces of broken XRF pills. The pit size was $90 \mathrm{~nm}$ for the sample material and $40 \mathrm{~nm}$ for the standard. Acquired raw data from the LA-ICP-MS analyses were processed with Signal Integration for Laboratory Laser Systems (SILLS) (Guillong et al. 2008). $\mathrm{CaO}$ or $\mathrm{Al}_{2} \mathrm{O}_{3}$ was used as internal standard depending on the concentration within each sample.

Representative polished thin sections were used to analyse the mineral chemistry of phenocrysts and micro-phenocrysts as well as to collect backscatter electron images 

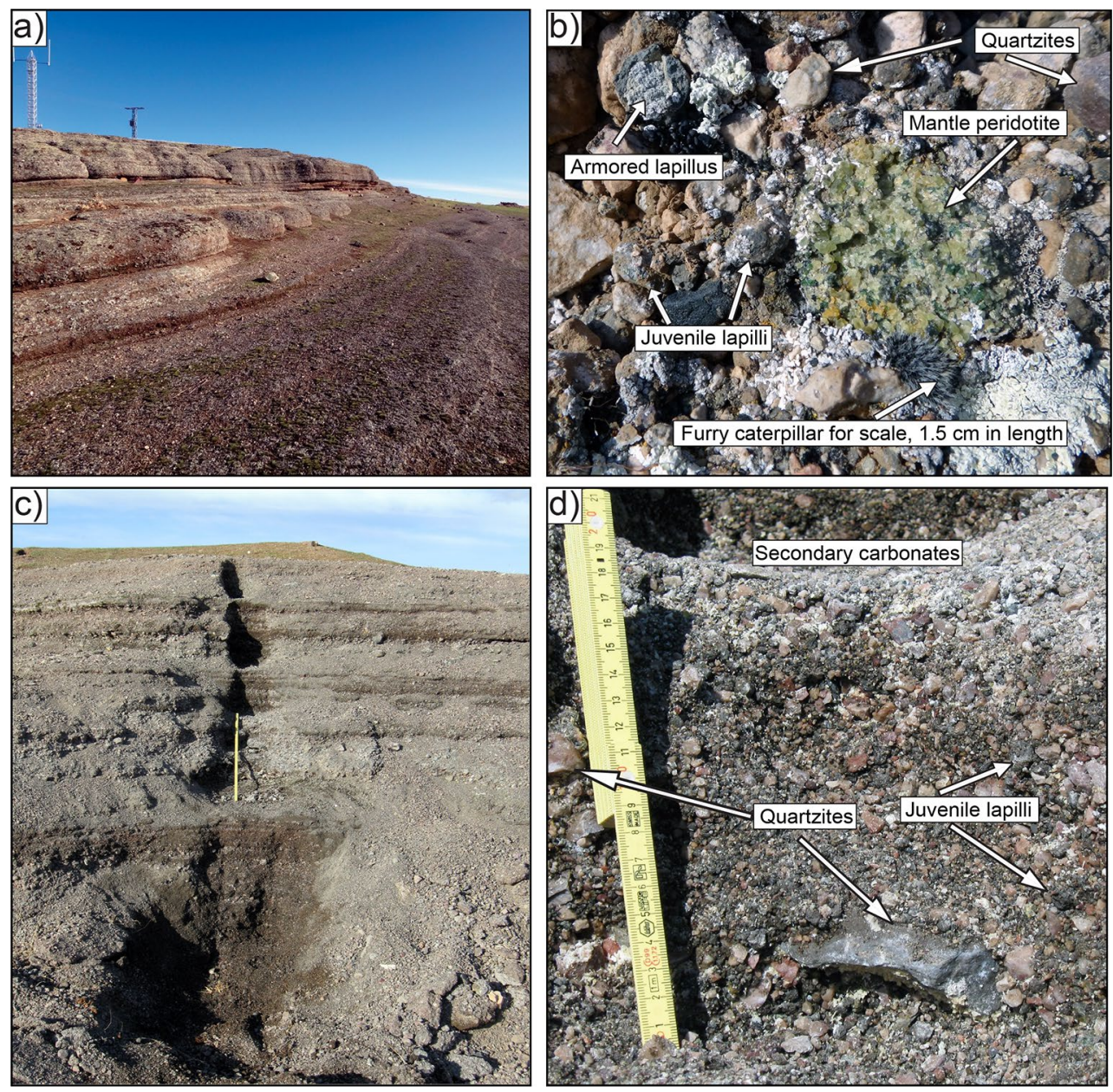

Fig. 2 Field characteristics of the Finca la Nava deposits. a Overview of the lower outcrop. b Close-up of the deposits in the lower outcrop. Also, note that peridotite fragments are frequently coated by juvenile melt, whereas quartzitic fragments seldom show coat-

ing by juvenile melt. c Overview of the upper outcrop. d Close-up of the upper outcrop. Detailed stratigraphic logs including the results of grain size distribution analyses are available in the Electronic Appendix

with the electron probe micro-analysis (EPMA) using a JEOL JXA-8200 equipped with five WDS crystal spectrometers. Operating conditions were an accelerating voltage of $15 \mathrm{kV}$, a beam current of $20 \mathrm{nA}$ and a spot size of $1-4 \mu \mathrm{m}$ in order to ensure as high spatial resolution as possible. The counting times were $20 \mathrm{~s}$ on the peak and $10 \mathrm{~s}$ on the background for all elements.

\section{Results}

\section{Stratigraphy and depositional characteristics}

As the main exposure and the crater floor of the Finca la Nava maar deposits are partially covered by debris and scree, we present here the stratigraphy of the two largest exposures independently of each other (Electronic Appendix). However, it is important to remember that both

outcrops are most likely representing one single continuous sequence only separated spatially by $\sim 150 \mathrm{~m}$.

\section{Lower outcrop}

The step-like lower outcrop at Finca la Nava measures approximately $5 \mathrm{~m}$ in total thickness (Fig. 2a and Electronic Appendix). It is composed of juvenile ash and lapilli as well as fragments of quartzites, slates and mantle xenoliths in various amounts, which have been cemented by secondary carbonate and zeolites. The juvenile pyroclasts are quite well-rounded, whereas the quartzites and slates have a more angular shape (Fig. 2b). The mantle xenoliths are partially weathered and are rounded to subangular (Fig. 2b). The material is horizontally, planarstratified without any apparent flow structures, except for some rare large-scale undulating structures. Overall, the lower outcrop has a rather fine-grained appearance (i.e. the 
lapilli fraction is nearly absent; see representative granulometric data in Electronic Appendix). The median particle diameter of nine representative samples from this outcrop ranges from -0.428 to $-2.207 M_{\mathrm{d}} \Phi$, which classifies them according to White and Houghton (2006) as a very coarse tuff to a fine lapilli-tuff deposit. The samples are unimodal and poorly to very poorly sorted $(1.303-2.379 \sigma \Phi)$. In the lower outcrop, the very fine-ash fraction $(<0.125 \mathrm{~mm})$ is relatively abundant (up to $4 \mathrm{wt} \%$ ).

The quartzites are by far the dominating type of accidental lithics in this deposit, and they occasionally reach sizes of up to $40 \mathrm{~cm}$ across. In addition to upper-crustal xenoliths, also mantle xenoliths (up to $26 \mathrm{~cm}$ across) occur throughout the eruptive sequence (Fig. 2b). They are more common in some layers than in others. Overall, the outcrop displays alternating layers of finer and coarser grain sizes, which are relatively well consolidated.

\section{Upper outcrop}

The upper outcrop is smaller than the lower one and measures $1.8 \mathrm{~m}$ in total thickness (Fig. 2c and Electronic Appendix). It has a similar step-like appearance in the field as the lower outcrop, but it is coarser-grained and also less well consolidated. It is composed of the same xenoliths and juvenile material as the lower outcrop (Fig. 2d). The juvenile material and the mantle xenoliths are rounded, whereas the quartzites and slates are more angular in shape. The outcrop is again horizontally, planar-stratified without any apparent flow structures. The largest clasts in the upper outcrop are the mantle xenoliths (up to $13 \mathrm{~cm}$ across), which makes them still smaller than that ones of the lower outcrop. Some layers are more consolidated as a result of cementation by secondary carbonates/zeolites (Fig. 2d) increasing the resistivity against weathering/erosion. This leads to the step-like shape of both outcrops.

Like the lower outcrop, there is an alternation between coarse- and fine-grained layers (Fig. 2c). The median particle diameter from the 14 representative samples (see Electronic Appendix) ranges from -1.050 to $-4.913 M_{\mathrm{d}} \Phi$. Also the upper outcrop is classified as a fine lapilli tuff to a coarse lapilli-tuff deposit even if it is less well consolidated (White and Houghton 2006). $50 \%$ of the samples are $>-2 \mathrm{M}_{\mathrm{d}} \Phi$ (compared with $22 \%$ for the lower outcrop). All samples are poorly sorted $(1.285$ to $2.003 \sigma \Phi)$. More than half of the samples are unimodal. The very fine-ash fraction is less abundant in the upper outcrop (with $<0.3 \mathrm{wt} \%$ ) in comparison with the lower outcrop. Hand-picked componentry reveals that in $85 \%$ of the samples, the largest amount of juvenile material is present in the 2 to $4 \mathrm{~mm}$ fraction reaching values of up to $12 \%$ of the class weight (Electronic Appendix). Overall, the sizes of the juvenile fragments as well as the average size of the quartzitic xenoliths increase with stratigraphic height, whereas the mantle xenoliths show an overall decrease in size for the same intervals.

\section{Petrography and mineral chemistry}

\section{Juvenile material}

Morphologically, the juvenile material is dominated by sub-spherical to spherical pyroclasts with moderate vesicularity (i.e. 5-45 \%; Fig. 3a, b). It occurs in all sizes ranging from fine-grained ash to bombs. Cored ashes and lapilli occur frequently within the deposits. The core is typically composed of a large phenocryst phase (predominantly clinopyroxene) or a mantle xenolith fragment, which are coated by a juvenile melt film (Figs. 2b, 3a, b). In particular, the occurrence of the cored lapilli is a common feature in the CVP region (Stoppa et al. 2012), and in some cases the pyroclasts occur as composite pyroclasts. The internal texture of the juvenile pyroclasts is best described as seriate-porphyritic with the main phenocryst phases being clinopyroxene, olivine, amphibole and phlogopite within a hemicrystalline groundmass composed of melilite, clinopyroxene and olivine. Spinel appears as an accessory phase. Furthermore, zeolites and secondary carbonate(s) occur as cementing material between juvenile material and country rock fragments, and occasionally as infilling of vesicles of the juvenile material.

Clinopyroxene, up to $15 \mathrm{~mm}$ in size, is the most abundant mineral in the juvenile material. They frequently display euhedral crystal shapes and often show strong internal zoning (Fig. 4a). From mineral chemistry analyses, it is possible to distinguish between several different types of pyroxenes. The most common types of pyroxenes are augites (Type 1a). They have magnesium numbers $\left(\# \mathrm{Mg}=100 * \mathrm{Mg} /\left[\mathrm{Mg}+\mathrm{Fe}^{2+}\right]\right)$ between 82 and 85 and are characterized by low $\mathrm{TiO}_{2}$ contents of 0.8 to $2.0 \mathrm{wt} \%$ (Fig. 4b). The second type (Type $1 \mathrm{~b}$ ) is also augitic in composition and frequently occurs as outer rim around the Type 1a augites (Fig. 4a) and around green-cored diopsides (Type 2). Type $1 \mathrm{~b}$ augites also occur as phenocryst in the groundmass with a subhedral crystal shape. In contrast to the Type 1a augites, Type $1 \mathrm{~b}$ is richer in $\mathrm{TiO}_{2}, \mathrm{Al}_{2} \mathrm{O}_{3}, \mathrm{FeO}$ and $\mathrm{CaO}$ as well as poorer in $\mathrm{SiO}_{2}$ and $\mathrm{MgO}$ (Table 1). They also have a broader range in \#Mg spanning from 68 to 80 , and the $\mathrm{TiO}_{2}$ contents are higher (3.0-7.8 wt\%; Fig. 4b). CaO varies between 22 and $24 \mathrm{wt} \%$, and the $\mathrm{SiO}_{2}$ values are rather low (i.e. down to $39 \mathrm{wt} \%$; Electronic Appendix). Similar Type $1 \mathrm{~b}$ clinopyroxenes are also described from other studies in the CVP (Cebriá and López-Ruiz 1995; Bailey et al. 2005). Green-cored diopside (Type 2) is also occurring fairly frequently. They are characterized by 


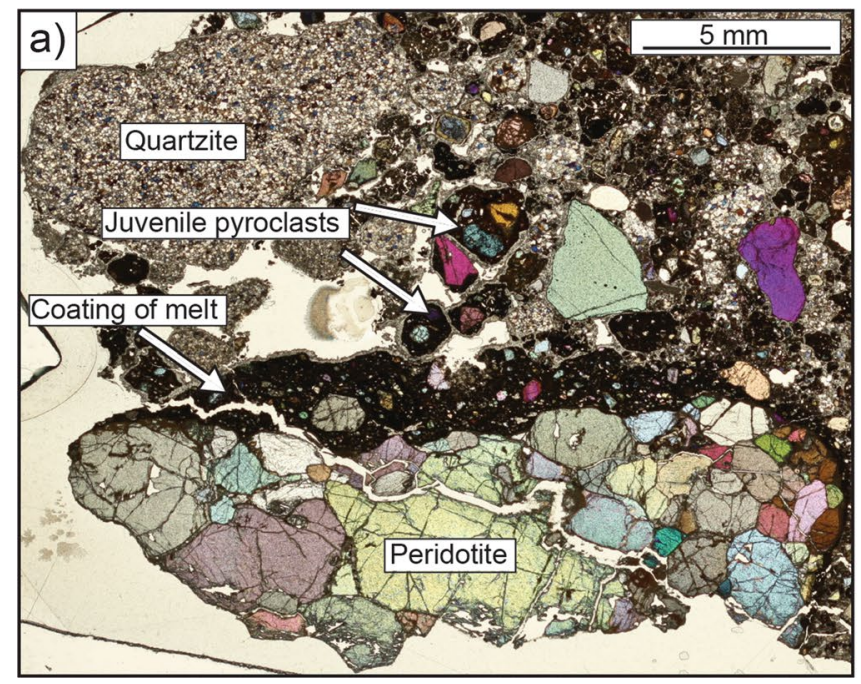

Fig. 3 Petrographic characteristics of the Finca la Nava deposits. a Overview of a near-complete thin section from the lower outcrop showing sub-rounded juvenile pyroclasts together with quartzitic and peridotitic fragments. b Image of a thin section showing dark juve-

high $\mathrm{FeO}$ and low $\mathrm{MgO}$ contents in the core (i.e. 13.2 and $9.6 \mathrm{wt} \%$, respectively; Electronic Appendix). The \#Mg and $\mathrm{TiO}_{2}$ contents range from 60 to 75 and from 0.3 to $1.8 \mathrm{wt} \%$, respectively (Fig. 4b). As mentioned before, some of the Type 2 clinopyroxenes are overgrown by an evolved augitic rim (Type 1b), but there are also several examples of green-core diopsides without rims. Finally, Type 3 clinopyroxenes have a quite primitive character with \#Mg clustering very tightly around 90, in combination with very low $\mathrm{TiO}_{2}$ contents (i.e. $<0.7 \mathrm{wt} \%$; Fig. $4 \mathrm{~b}$ ). Orthopyroxene (i.e. enstatite) also occurs sporadically within the juvenile material. Similar to the Type 3 clinopyroxenes, they have a primitive character with high \#Mg of $\sim 90$ (Table 1) and show signs of disequilibrium such as resorption. These crystals are frequently overgrown by an augitic Type $1 \mathrm{~b}$ rim (Fig. 4c).

Olivine is a ubiquitous mineral in the Finca la Nava juvenile material that occurs as phenocryst (Fig. 5a) and as micro-phenocrysts in the groundmass. Like for the clinopyroxenes, there are at least two distinct populations of olivine present. Type 1 olivines display a positive correlation between forsterite contents of $\mathrm{Fo}_{88}$ to $\mathrm{Fo}_{83}$ and $\mathrm{NiO}$ contents of $0.08-0.38 \mathrm{wt} \%$ (Fig. 5b). They partly show weak chemical internal zoning with rims enriched in $\mathrm{CaO}$ (Fig. 5a and Electronic Appendix). Type 2 olivines have a rather primitive character with forsterite contents ranging from $\mathrm{Fo}_{91}$ to $\mathrm{Fo}_{88}$. They are also clustering tightly at higher $\mathrm{NiO}$ values $(\sim 0.3-0.4 \mathrm{wt} \%)$ compared to Type 1 olivines (Fig. 5b).

Amphiboles are the third most common mineral phase in the Finca la Nava juvenile material, and they reach sizes of

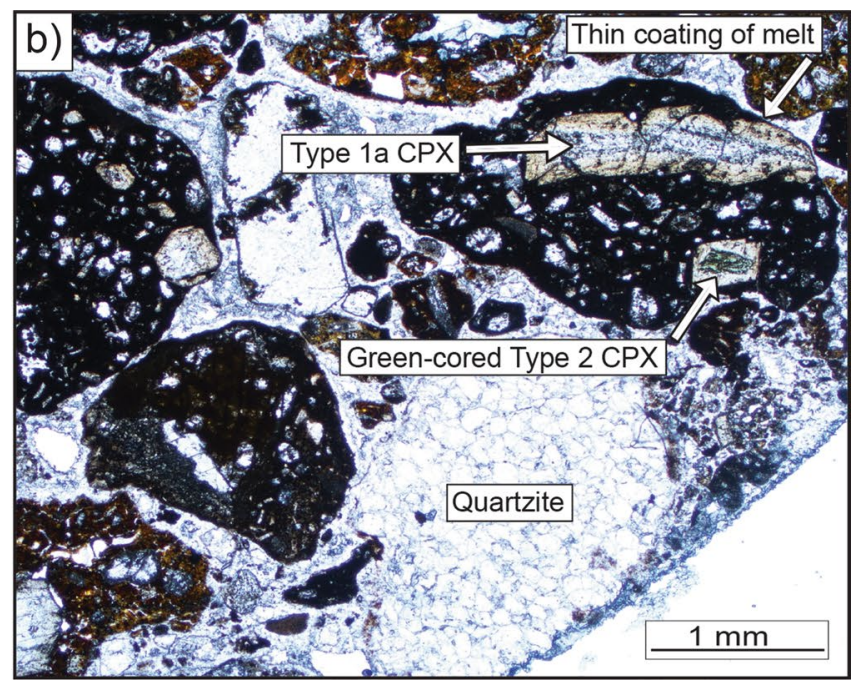

nile fragments characterized by rounded fluidal shapes and moderate vesicularity. Note the thin melt coating surrounding the clinopyroxene in the upper right corner (indicated by arrow)

up to $5 \mathrm{~mm}$, but typically they are around $0.5 \mathrm{~mm}$ in size. They have relatively high $\mathrm{TiO}_{2}$ contents of up to $4.2 \mathrm{wt} \%$ (Electronic Appendix) and are thus classified as pargasitic amphiboles.

The micas in the Finca la Nava deposits classify as phlogopites based on their high $\mathrm{MgO}$ contents of up $19 \mathrm{wt} \%$ (Electronic Appendix). They are characterized by \#Mg of 84.5 to 86 as well as high $\mathrm{TiO}_{2}$ contents of $5-6 \mathrm{wt} \%$ in combination with low $\mathrm{NiO}$ contents of $<0.12 \mathrm{wt} \%$ (Electronic Appendix). The phlogopites occur as crystals reaching sizes of up to 4-5 mm across. They commonly show resorption textures and are often surrounded by a very thin opaque rim. It is interesting to note that most phlogopites show this sub-rounded morphologies and reaction rims except when they are present as euhedral inclusions in Type 1a clinopyroxenes.

In terms of groundmass minerals, melilite is (beside clinopyroxene and olivine) the most abundant one. The mineral occurs as small laths and shows its typical tabular structure (Fig. 4c). Unfortunately, it was not possible to obtain satisfying chemical melilite compositions with the microprobe due to alteration. Similar problems are reported in other studies (Berghuijs and Mattsson 2013). Opaque phases occur sparsely in the juvenile material. From these, euhedral ulvöspinel was identified together with high $\mathrm{MgO}$, low $\mathrm{Cr}_{2} \mathrm{O}_{3} \mathrm{FeO}$-hercynite and titanomagnetite.

\section{Accidental crustal lithics}

There are two main types of accidental crustal lithics present in the FIN deposits: (1) quartzites and (2) slates. 

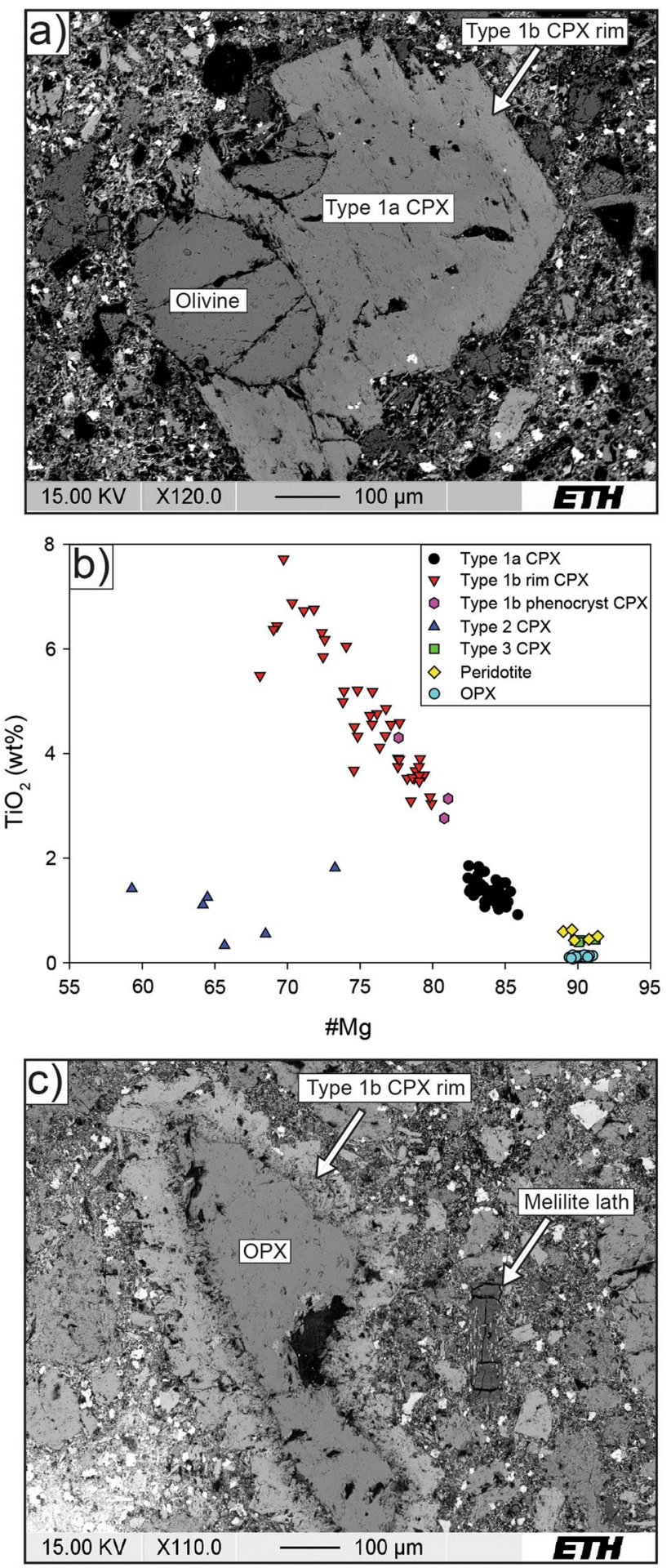

Fig. 4 Petrography and mineral chemistry of pyroxenes. a Backscattered SEM image showing an euhedral and cored augite crystal (Type 1a) surrounded by a more evolved rim (Type 1b). Two rounded olivines are present as in inclusions in the pyroxene. b Plot of \#Mg versus $\mathrm{TiO}_{2}$ content showing a negative correlation for the different types of FIN pyroxenes. c Orthopyroxene with an overgrowth of augitic composition (i.e. Type 1b)
Quartzite makes up the largest portion in each layer of the whole deposit (up to $>60 \mathrm{vol} \%$ ), which was determined by sieving and field observations. The slates are much less common $(<5$ vol\% in all investigated layers). Both types of xenoliths show sub-angular to angular morphologies in hand specimen. Both xenoliths also occur occasionally as disintegrated material due to the breakdown of small parts of the quartzite, for instance by mechanical milling, and they were incorporated in the juvenile magma. Because the mineralogy of these uppercrustal lithics (dominated by quartz and feldspars) is far from what would be expected to be found in silica-undersaturated system such as FIN, we did not do any further detailed microprobe analyses of the mineral chemistry in these rocks but instead focused on whole-rock analyses (see Sect. 4.3.2).

\section{Mantle xenoliths}

Mantle xenoliths occur dispersed throughout the stratigraphic sequence at Finca la Nava, and they are sometimes also incorporated into the juvenile material like the crustal lithics (Fig. 3a). These peridotitic xenoliths are characterized by a four-phase mineral assemblage comprising olivine, orthopyroxene, clinopyroxene and spinel. From the visual volumetric proportion estimation, they are best classified as lherzolites, which is in agreement with other studies (Bianchini et al. 2010; Villaseca et al. 2010). The minerals have a euhedral to subhedral equigranular (protogranular) texture, and the grain size is uniform ranging between 0.5 and $1 \mathrm{~mm}$ (maximum size is $\sim 5 \mathrm{~mm}$ ). Grain boundaries are curvilinear and mostly defined by mosaic or triple-junction textures.

The clinopyroxenes classify as augites with a very uniform clustering of \#Mg at 89-90, combined with relatively low $\mathrm{TiO}_{2}$ contents of 0.4 to $0.6 \mathrm{wt} \%$ (Fig. $4 \mathrm{~b}$ ). They are thus identical in composition to the Type 3 clinopyroxenes found in the juvenile material. Similarly, the orthopyroxenes classify as enstatites, and they are also identical to the orthopyroxenes found in the juvenile material. The olivines in the peridotitic xenoliths also have uniform forsterite contents of $\mathrm{Fo}_{>88}$ and consistently high $\mathrm{NiO}$ content of $>0.3 \mathrm{wt} \%$. Thus again, olivine compositions from the peridotites completely overlap with the Type 2 olivines in the juvenile material (Fig. 5b). Type 3 clinopyroxenes, Type 2 olivines and enstatites found in the juvenile material were thus brought there by disintegration of the mantle xenoliths. The opaque phases, represented by ilmenite and high $\mathrm{MgO}, \mathrm{Cr}_{2} \mathrm{O}_{3}$ and low $\mathrm{FeO}$-hercynite, are typically situated in the interstitial spaces as discrete grains between the olivines, clinopyroxenes and orthopyroxenes. 
Table 1 LOI corrected major (wt\%) and trace element (ppm) analysis of the juvenile and the accidental lithics from Finca la Nava maar

\begin{tabular}{|c|c|c|c|c|c|c|c|c|c|c|c|c|c|}
\hline \multirow{2}{*}{$\begin{array}{l}\text { Material } \\
\text { Sample }\end{array}$} & \multicolumn{10}{|c|}{ Juvenile material } & \multicolumn{3}{|c|}{ Accidental lithics } \\
\hline & $\mathrm{J} 3 \mathrm{a}$ & $\mathrm{J} 3 \mathrm{c}$ & J3d & $\mathrm{J} 3 \mathrm{e}$ & $\mathrm{J} 3 \mathrm{~g}$ & $\mathrm{~J} 3 \mathrm{j}$ & $\mathrm{J} 3 \mathrm{k}$ & $J 3 n$ & $\mathrm{~J} 3 \mathrm{p}$ & $\begin{array}{l}\text { Avg. } \\
n=9\end{array}$ & $\begin{array}{l}\text { Mantle } \\
n=3\end{array}$ & $\begin{array}{l}\text { Quart. } \\
n=2\end{array}$ & $\begin{array}{l}\text { Slate } \\
n=1\end{array}$ \\
\hline $\mathrm{SiO}_{2}(\mathrm{wt} \%)$ & 44.0 & 43.6 & 42.8 & 45.0 & 42.2 & 43.4 & 43.8 & 45.8 & 44.0 & 43.9 & 44.6 & 97.6 & 68.8 \\
\hline $\mathrm{TiO}_{2}$ & 2.6 & 2.3 & 2.5 & 2.6 & 2.6 & 2.9 & 2.9 & 2.0 & 2.7 & 2.6 & 0.1 & 0.1 & 1.0 \\
\hline $\mathrm{Al}_{2} \mathrm{O}_{3}$ & 8.3 & 7.5 & 8.0 & 8.2 & 8.0 & 8.6 & 8.6 & 7.6 & 8.8 & 8.2 & 3.1 & 1.8 & 21.0 \\
\hline $\mathrm{Fe}_{2} \mathrm{O}_{3}$ & 11.4 & 10.8 & 11.1 & 11.5 & 11.9 & 11.4 & 11.9 & 9.4 & 11.0 & 11.2 & 9.0 & 0.1 & 3.2 \\
\hline $\mathrm{MnO}$ & 0.2 & 0.2 & 0.2 & 0.2 & 0.2 & 0.2 & 0.2 & 0.1 & 0.2 & 0.2 & 0.1 & 0.0 & 0.0 \\
\hline $\mathrm{MgO}$ & 20.0 & 21.1 & 19.5 & 19.3 & 21.3 & 17.9 & 18.3 & 18.8 & 18.8 & 19.4 & 39.9 & 0.0 & 0.3 \\
\hline $\mathrm{CaO}$ & 11.3 & 11.7 & 12.8 & 10.8 & 11.3 & 13.5 & 12.6 & 14.2 & 12.1 & 12.3 & 2.9 & 0.0 & 0.0 \\
\hline $\mathrm{Na}_{2} \mathrm{O}$ & 0.5 & 0.9 & 1.0 & 0.8 & 0.8 & 0.7 & 0.3 & 1.0 & 0.8 & 0.8 & 0.0 & 0.0 & 0.1 \\
\hline $\mathrm{K}_{2} \mathrm{O}$ & 0.4 & 0.9 & 0.9 & 0.7 & 0.6 & 0.4 & 0.3 & 0.5 & 0.6 & 0.6 & 0.0 & 0.0 & 5.2 \\
\hline $\mathrm{P}_{2} \mathrm{O}_{5}$ & 0.7 & 0.6 & 0.7 & 0.7 & 0.8 & 0.8 & 0.7 & 0.4 & 0.7 & 0.7 & 0.0 & 0.0 & 0.1 \\
\hline Total: & 99.4 & 99.6 & 99.5 & 99.7 & 99.6 & 99.8 & 99.6 & 99.9 & 99.7 & 99.6 & 99.8 & 99.7 & 99.8 \\
\hline $\mathrm{Mg \#}$ & 77.6 & 79.5 & 77.7 & 76.9 & 77.9 & 75.6 & 75.4 & 79.8 & 77.1 & 77.5 & 89.8 & 3.1 & 17.0 \\
\hline $\mathrm{Sc}(\mathrm{ppm})$ & 26.0 & 28.1 & 28.1 & 25.0 & 26.4 & 31.5 & 26.8 & 35.8 & 29.5 & 28.6 & 14.6 & 1.8 & 14.0 \\
\hline V & 189.9 & 202.2 & 201.6 & 180.8 & 193.1 & 214.0 & 169.2 & 226.5 & 224.2 & 200.2 & 63.4 & 1.8 & 91.2 \\
\hline $\mathrm{Cr}$ & 1049.2 & 1230.4 & 1007.6 & 872.3 & 928.6 & 883.3 & 837.4 & 1067.6 & 1023.0 & 988.8 & 2421.5 & 13.9 & 53.7 \\
\hline Co & 64.9 & 62.4 & 63.4 & 58.9 & 65.1 & 55.3 & 60.8 & 56.5 & 61.2 & 60.9 & 96.5 & 4.8 & 1.7 \\
\hline $\mathrm{Ni}$ & 620.8 & 686.0 & 605.1 & 511.4 & 620.0 & 453.9 & 550.6 & 523.1 & 526.4 & 566.4 & 1776.7 & 85.8 & 14.6 \\
\hline $\mathrm{Cu}$ & 38.8 & 31.0 & 32.9 & 39.7 & 35.0 & 32.6 & 42.8 & 27.3 & 37.5 & 35.3 & 16.9 & 2.1 & 10.6 \\
\hline $\mathrm{Ga}$ & 13.8 & 11.4 & 14.1 & 12.0 & 12.2 & 13.6 & 13.8 & 12.3 & 13.4 & 12.9 & 2.6 & 2.4 & 19.2 \\
\hline $\mathrm{Rb}$ & 36.6 & 39.8 & 40.3 & 40.0 & 53.8 & 44.8 & 21.7 & 31.8 & 45.6 & 39.4 & 0.6 & 0.5 & 2.4 \\
\hline $\mathrm{Sr}$ & 426.4 & 505.6 & 554.7 & 464.8 & 507.0 & 527.7 & 432.4 & 432.2 & 518.2 & 485.4 & 22.2 & 18.7 & 110.2 \\
\hline $\mathrm{Y}$ & 21.5 & 21.4 & 21.4 & 23.1 & 23.0 & 25.5 & 24.5 & 16.5 & 21.6 & 22.0 & 2.9 & 14.4 & 29.4 \\
\hline $\mathrm{Zr}$ & 248.8 & 230.8 & 283.4 & 281.9 & 262.6 & 298.7 & 301.3 & 172.5 & 262.9 & 260.3 & 7.4 & 33.1 & 370.8 \\
\hline $\mathrm{Nb}$ & 76.4 & 66.7 & 73.2 & 82.3 & 79.6 & 84.5 & 85.0 & 44.4 & 69.9 & 73.5 & 1.9 & 1.8 & 14.7 \\
\hline Mo & 1.2 & 2.9 & 3.4 & 1.9 & 2.2 & 1.7 & 0.8 & 2.7 & 2.2 & 2.1 & 0.2 & 1.9 & 0.4 \\
\hline Cs & 1.0 & 0.6 & 0.7 & 0.8 & 1.0 & 0.7 & 0.4 & 0.5 & 0.8 & 0.7 & 0.0 & b.d.l. & 4.7 \\
\hline $\mathrm{Ba}$ & 668.0 & 739.0 & 770.0 & 738.4 & 685.8 & 642.2 & 572.5 & 414.9 & 657.7 & 654.3 & 16.1 & 94.0 & 763.0 \\
\hline $\mathrm{La}$ & 63.4 & 57.5 & 59.1 & 66.3 & 66.8 & 71.6 & 69.8 & 37.1 & 59.6 & 61.2 & 1.3 & 10.4 & 40.9 \\
\hline $\mathrm{Ce}$ & 123.4 & 103.5 & 113.7 & 124.6 & 124.3 & 132.0 & 130.5 & 74.5 & 118.7 & 116.1 & 2.8 & 25.6 & 77.0 \\
\hline $\operatorname{Pr}$ & 14.1 & 11.8 & 12.9 & 14.2 & 14.1 & 15.4 & 15.0 & 8.6 & 13.4 & 13.3 & 0.3 & 2.7 & 9.2 \\
\hline $\mathrm{Nd}$ & 56.8 & 49.0 & 52.7 & 57.2 & 56.7 & 62.6 & 62.5 & 35.5 & 53.2 & 54.0 & 1.6 & 10.7 & 35.8 \\
\hline $\mathrm{Sm}$ & 10.0 & 8.8 & 9.6 & 9.7 & 10.2 & 11.8 & 10.8 & 7.6 & 9.9 & 9.8 & 0.4 & 2.7 & 8.2 \\
\hline $\mathrm{Eu}$ & 2.8 & 2.5 & 2.7 & 2.9 & 2.7 & 3.1 & 3.2 & 1.8 & 2.9 & 2.7 & 0.0 & 0.7 & 1.3 \\
\hline $\mathrm{Gd}$ & 7.4 & 6.7 & 7.9 & 8.0 & 9.0 & 9.4 & 8.7 & 6.0 & 8.2 & 7.9 & 0.1 & 4.6 & 5.6 \\
\hline $\mathrm{Tb}$ & 1.0 & 0.9 & 1.0 & 1.0 & 1.0 & 1.1 & 1.1 & 0.7 & 1.1 & 1.0 & 0.1 & 0.8 & 0.9 \\
\hline Dy & 5.1 & 5.4 & 4.8 & 5.5 & 5.5 & 5.9 & 5.7 & 3.6 & 5.3 & 5.2 & 0.4 & 3.5 & 4.8 \\
\hline Но & 0.9 & 1.0 & 0.8 & 0.9 & 0.9 & 1.0 & 1.0 & 0.6 & 0.8 & 0.9 & 0.1 & 0.5 & 1.1 \\
\hline Er & 2.2 & 2.6 & 1.7 & 1.6 & 1.7 & 2.1 & 2.6 & 1.6 & 2.0 & 2.0 & 0.1 & 1.2 & 3.5 \\
\hline $\mathrm{Tm}$ & 0.2 & 0.2 & 0.3 & 0.2 & 0.2 & 0.2 & 0.2 & 0.1 & 0.2 & 0.2 & 0.0 & 0.1 & 0.4 \\
\hline $\mathrm{Yb}$ & 1.4 & 1.9 & 1.3 & 1.2 & 1.3 & 1.6 & 1.8 & 1.2 & 1.5 & 1.5 & 0.4 & 1.1 & 3.5 \\
\hline $\mathrm{Lu}$ & 0.1 & 0.2 & 0.3 & 0.3 & 0.3 & 0.3 & 0.3 & 0.2 & 0.2 & 0.2 & 0.1 & 0.2 & 0.5 \\
\hline $\mathrm{Hf}$ & 5.9 & 5.5 & 7.1 & 6.1 & 6.0 & 7.2 & 6.9 & 4.5 & 6.4 & 6.2 & 0.1 & 2.6 & 10.4 \\
\hline $\mathrm{Ta}$ & 4.7 & 4.2 & 4.4 & 5.0 & 4.9 & 5.6 & 5.4 & 2.7 & 3.9 & 4.5 & 0.1 & 0.3 & 1.2 \\
\hline $\mathrm{Pb}$ & 2.8 & 2.1 & 2.6 & 3.0 & 3.1 & 2.9 & 3.0 & 1.5 & 2.1 & 2.6 & 0.1 & 1.2 & 5.0 \\
\hline Th & 8.1 & 7.3 & 7.7 & 10.3 & 8.7 & 9.7 & 9.4 & 4.7 & 8.3 & 8.3 & 0.2 & 2.7 & 16.2 \\
\hline $\mathrm{U}$ & 1.4 & 1.5 & 1.7 & 1.7 & 1.7 & 1.6 & 1.2 & 1.0 & 1.5 & 1.5 & 0.1 & 1.0 & 3.5 \\
\hline
\end{tabular}



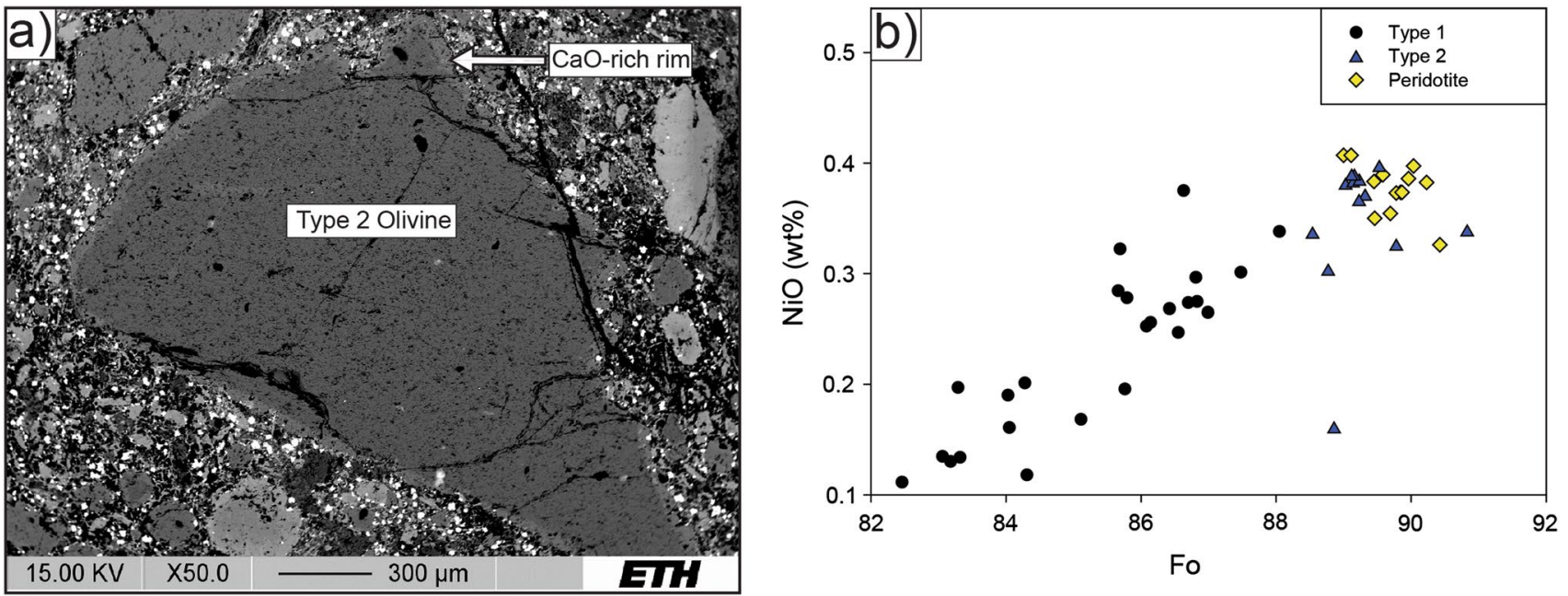

Fig. 5 Petrography and mineral chemistry of olivines. a Backscattered SEM image showing a subhedral olivine crystal (Type 2) overgrown by a more evolved $\mathrm{CaO}$-rich rim. b Plot of $\mathrm{Fo}$ versus $\mathrm{NiO}$ showing a positive correlation for olivines

\section{Geochemistry}

In this paragraph, we examine the compositional variations within the dominant lithologies and the individual components as well as the geochemical variation as a function of stratigraphic height. A similar approach was used by Brenna et al. (2011) and McGee et al. (2012) who looked at the geochemical variations in the juvenile material with stratigraphic height linking their results to a more complex melting, mixing and eruption history than the term "monogenetic" of Walker (1993) implies. As shown by Berghuijs and Mattsson (2013), bulk rock analyses of the different lithofacies can be interpreted as a variable mixing of juvenile material, crustal lithics and mantle xenoliths due to changes in the fragmentation intensities. We look at the variations in the bulk rock compositions of the different lithofacies, which should thus be indicative for changes in the magma and country rock fragmentation level within the conduit, and it may also show how the fragmentation efficiency/intensity changed with time during the eruption.

The major elements were determined by XRF-analysis and the trace elements by LA-ICP-MS. In total, 43 analyses were performed with 28 samples represent bulk rock compositions from various stratigraphic height, nine comprise the hand-picked juvenile material from the upper outcrop, three the mantle xenoliths, two quartzites and one slate sample.

\section{Juvenile material}

For the nine hand-picked samples of the juvenile pyroclasts, the $\mathrm{SiO}_{2}$ content varies between 42.2 and $45.8 \mathrm{wt} \%$ (Table 1) and they plot as picro-basalt to basalt in the TAS diagram (Fig. 6a). However, this diagram is not very useful in distinguishing between different silica-undersaturated rocks. When plotted in the combined oxide diagram of Bas (1989), which also includes $\mathrm{CaO}$ and $\mathrm{Al}_{2} \mathrm{O}_{3}$, they predominantly plot as nephelinites (Fig. 6b).

Overall, the juvenile material displays a range in \#Mg from 75.4 to 79.8. In the $\# \mathrm{Mg}$ variations diagrams, $\mathrm{SiO}_{2}$ scatters slightly and shows clear negatively correlated trends for $\mathrm{TiO}_{2}$ and $\mathrm{Al}_{2} \mathrm{O}_{3}$ (Fig. 6c-e). The same is valid for $\mathrm{MnO}$ and $\mathrm{P}_{2} \mathrm{O}_{5}$ and a slightly negative trend for $\mathrm{CaO}$, whereas $\mathrm{K}_{2} \mathrm{O}$ and $\mathrm{Na}_{2} \mathrm{O}$ show positive trends (Electronic Appendix). The inter-element ratio $(\mathrm{La} / \mathrm{Nb})$ of light rare earth elements (LREE) to high field strength elements (HFSE) is constant at around 0.8 (Fig. 6f), which is in the range of previous studies in the CVP (Cebriá and López-Ruiz 1996). The juvenile samples have a high concentration of REE normalized to chondritic meteorite values (Mcdonough and Sun 1995). The trends show a pattern, which is common for alkali basaltic magmas (Cebriá and López-Ruiz 1996) with a stronger enrichment of the LREE in comparison with the heavy rare earth elements (HREE). The enrichment of LREE ranges from 32.75 to 301 times of chondritic values (Fig. 7a). They display a relative enrichment in the LREE with $[\mathrm{Ce} / \mathrm{Yb}]_{\mathrm{n}}$ ratios varying from 15.5 to 27.8 (Electronic Appendix), which is similar to that reported from melilitites in the East African Rift of northern Tanzania (Mattsson et al. 2013). The incompatible trace elements diagram for the juvenile samples displays a highly fractionated pattern and an overall enrichment of all elements compared to the primitive mantle (Mcdonough and Sun 1995). In general, a decreasing trend from Ta to $\mathrm{Lu}$ is observable. A slightly weaker enrichment in the low-valency cations $\mathrm{Cs}, \mathrm{Rb}$ and $\mathrm{Ba}$ and a weak enrichment in $\mathrm{K}$ and $\mathrm{Pb}$ are visible (Fig. 7b). 

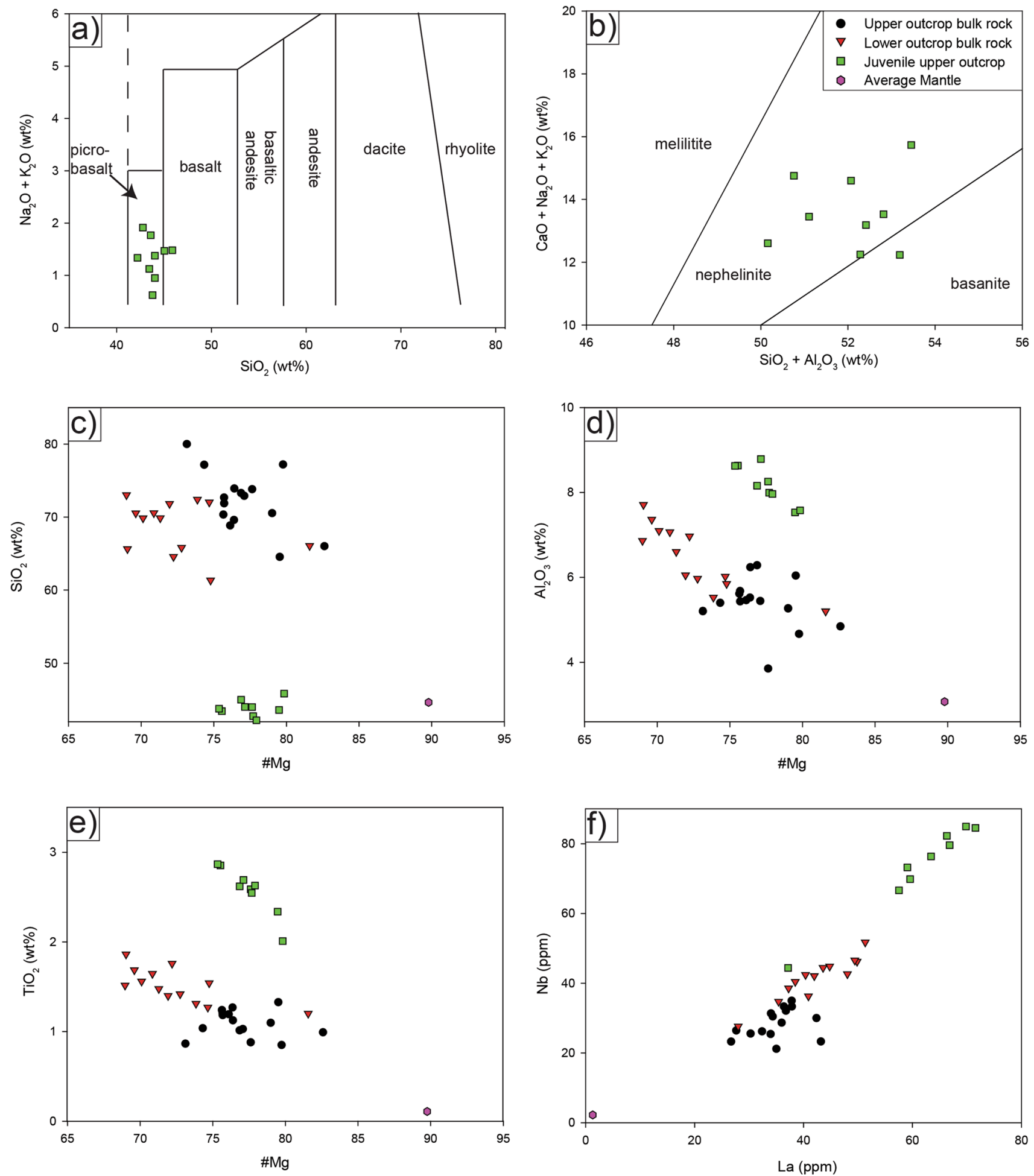

Fig. 6 Classification of the juvenile and the bulk rock samples of the upper and lower outcrop. a TAS diagram after Bas et al. (1986). b Combined oxide diagram after Bas (1989). Representative \#Mg varia-

tion diagrams for $\mathbf{c} \mathrm{SiO}_{2}, \mathbf{d ~} \mathrm{Al}_{2} \mathrm{O}_{3}$ and $\mathbf{e} \mathrm{TiO}_{2}$. f Inter-element diagram with the plot LREE (La) against HFSE $(\mathrm{Nb})$ 
Fig. 7 Trace element plots with the LA-ICP-MS data. a REE abundance normalized to chondritic values after Mcdonough and Sun (1995). b Incompatible trace element abundance normalized to the primitive mantle after Mcdonough and Sun (1995)
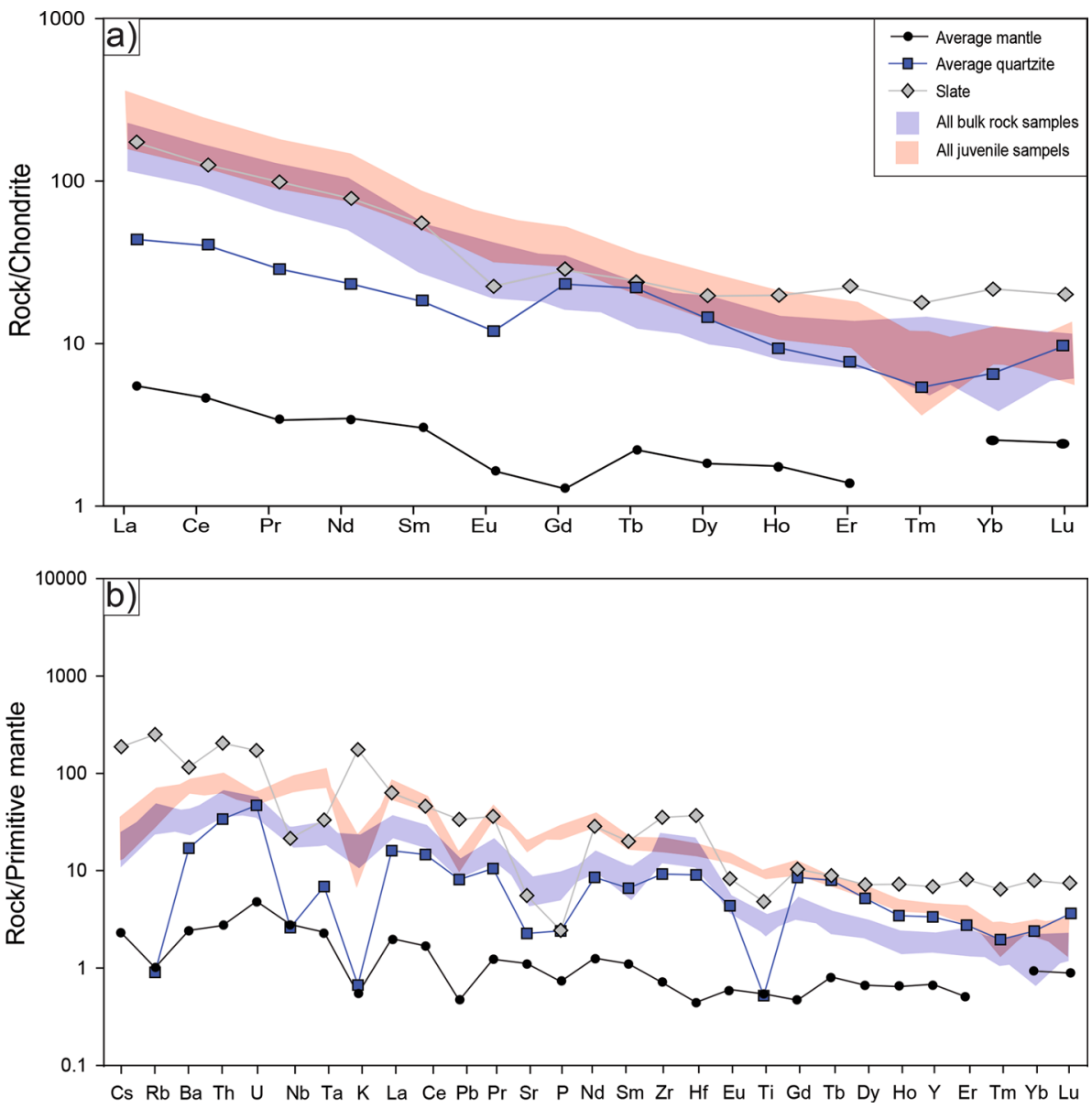

\section{Accidental crustal lithics}

The geochemistry of the crustal lithics is rather straightforward and uncomplicated. The quartzites show major and trace elements compositions, which are characterized by $\mathrm{SiO}_{2}$ and $\mathrm{Al}_{2} \mathrm{O}_{3}$ contents of 97.6 and $1.8 \mathrm{wt} \%$, respectively. They are the only major elements in the quartzites (Table 1 ). The ratios of LREE/HFSE are with 5.8 higher than that of the juvenile material (Fig. 6f) pointing to a stronger depletion in the HFSE in comparison with the LREE. The REEs have a decreasing trend with a jump from Eu to $\mathrm{Gd}$, but overall, they are one order of magnitude lower than the juvenile samples (Fig. 7a). For the incompatible trace elements, a different picture is presented referring the element proportion. There is depletion for the elements $\mathrm{Rb}, \mathrm{K}$ and $\mathrm{Ti}$ compared to the primitive mantle. All the other elements are enriched. All in all, the pattern goes up from $\mathrm{Rb}$ to $\mathrm{U}$ and down to $\mathrm{K}$. From $\mathrm{La}$ to $\mathrm{Lu}$, the trend goes more or less constantly downwards with small evasion (Sr, P, Ti) (Fig. 7b).

The slates have high $\mathrm{SiO}_{2}$ and $\mathrm{Al}_{2} \mathrm{O}_{3}$ values of 68.8 and $21.0 \mathrm{wt} \%$, respectively, and low $\mathrm{K}_{2} \mathrm{O}$ and $\mathrm{Fe}_{2} \mathrm{O}_{3}$ values of 5.2 and $3.2 \mathrm{wt} \%$, respectively. The other elements are below $1 \mathrm{wt} \%$ (Table 1). The ratios of LREE/HFSE are with values of around 2.8 in the same range as the quartzites (Fig. 6f), and also the REE pattern is very similar to the quartzites with the only difference that they are higher enriched (Fig. 7a). The incompatible trace elements are characterized by an overall decreasing trend, but compared to the quartzites they are much more enriched compared to the primitive mantle. In particular, from $\mathrm{Cs}$ to $\mathrm{U}$ and for $\mathrm{K}$, a strong enrichment is visible. The pattern shows some negative anomalies for $\mathrm{Nb}, \mathrm{Ta}, \mathrm{P}, \mathrm{Sr}$ and Ti (Fig. 7b).

\section{Mantle xenoliths}

The mantle xenoliths are characterized by uniform high \#Mg with an average value of 89.8 (Fig. 6c). The Ni and $\mathrm{Cr}$ contents a relatively high with up to $1776 \mathrm{ppm}$ and $2451 \mathrm{ppm}$ for the average values, respectively (Table 1), which is in agreement with other studies (Bianchini et al. 2010; Villaseca et al. 2010). The ratios for LREE/HFSE are with 0.6 in the same range as the juvenile material (Fig. 6f). The average mantle xenolith follows the REE pattern of the juvenile samples. But they show a turn from a decreasing trend to an increasing one from Gd to Tb. Overall, the enrichment of the mantle xenoliths is more than one 
order of magnitude lower in comparison with the juvenile samples (Fig. 7a). They show a very weak enrichment of incompatible trace elements, and they are depleted in some elements ( $\mathrm{Rb}, \mathrm{K}, \mathrm{Pb}, \mathrm{P}, \mathrm{Zr}-\mathrm{Gd})$ with respect to the values of the primitive mantle (Fig. 7b). They have a very similar pattern as the juvenile material, but they are more than one order of magnitude lower.

\section{Bulk rock compositional variation as a function of stratigraphic height}

Thirteen bulk rock analyses were performed for the lower outcrop and 15 for the upper one (Table 2). Silica is the most prominent element with concentrations ranging from 61.3 to $80.0 \mathrm{wt} \% \mathrm{SiO}_{2}$ depending on the ratio of crustal lithic/juvenile material, which will be discussed in Sect. 5.1. The \#Mg of the lower outcrop ranges from 69.0 to 81.6 with a slightly positive correlated trend for $\mathrm{SiO}_{2}$ (Fig. 6c) and clear negatively correlated trends for $\mathrm{Al}_{2} \mathrm{O}_{3}$ and $\mathrm{TiO}_{2}$ (Fig. 6d, e). The same is valid for $\mathrm{K}_{2} \mathrm{O}, \mathrm{P}_{2} \mathrm{O}_{5}$ and with a scatter for $\mathrm{MnO}$. $\mathrm{CaO}$ and $\mathrm{Na}_{2} \mathrm{O}$ have rough positive correlations with \#Mg (Electronic Appendix). In the upper outcrop, the \#Mg ranges from 73.1 to 82.6 with $\mathrm{SiO}_{2}, \mathrm{Al}_{2} \mathrm{O}_{3}$ and $\mathrm{TiO}_{2}$ showing negatively correlated trends (Fig. 6c-e). Also the trends for $\mathrm{K}_{2} \mathrm{O}, \mathrm{P}_{2} \mathrm{O}_{5}$ and $\mathrm{MnO}$ show negative trends, whereas $\mathrm{CaO}$ and $\mathrm{Na}_{2} \mathrm{O}$ show slightly positive trends (Electronic Appendix).

The LREE/HFSE ratio ranges for both outcrops from 1.08 to 1.86 , which is a bit higher than in the juvenile samples (Fig. 6f). The pattern of the REE is very similar to the juvenile samples with a decreasing trend. The enrichment for the LREE ranges from 18 to 216 times of chondritic meteorite values (Fig. 7a). For both outcrops, the incompatible trace element diagram shows an overall enrichment of all elements with respect to the primitive mantle values. In general, a relative depletion from $\mathrm{Th}$ to $\mathrm{Lu}$ is observable. The pattern is very similar to the upper juvenile samples with weaker enrichment in $\mathrm{Nb}$ and $\mathrm{Ta}$ and stronger enrichments in $\mathrm{K}, \mathrm{Pb}, \mathrm{Zr}$ and $\mathrm{Hf}$ (Fig. 7b).

The bulk rock samples show relatively strong compositional changes with stratigraphic height, which are most likely related to changes in the amount of picked up mantle xenoliths during the ascent of the magma and/or to changes in the locus of the explosion within the conduit [either by a progressive deepening and widening diatreme (Lorenz 1986) or by a series of explosions occurring at different depth leading to a mixing of the material by vertically directed debris jets and downward subsidence (Valentine and White 2012)]. There is a clear decreasing trend with stratigraphic height for $\mathrm{TiO}_{2}$ and $\mathrm{Y}$ (Fig. 8a, b). Furthermore, there is a clearly increasing $\mathrm{SiO}_{2}$ content with stratigraphic height (Fig. 8c) as well as increasing $\mathrm{Fe}_{2} \mathrm{O}_{3}^{\mathrm{T}} / \mathrm{TiO}_{2}$ ratios over the whole period of the eruption (Fig. 8d).

\section{Discussion}

\section{Classification of the FIN magma and its petrogenesis}

A classification of the Finca la Nava magma poses some problems because even the composition of the hand-picked juvenile material is partially overprinted by disintegration of mantle xenoliths and upper-crustal lithics. It is clear that some of the mineral phases in the juvenile material are identical in composition with the peridotitic material and are thus considered to be xenocrysts derived from disintegration of larger peridotite fragments (i.e. Type 3 clinopyroxenes, Type 2 olivines, orthopyroxene and hercynite). Also, from the geochemistry of the juvenile samples (average $\mathrm{SiO}_{2}=43.9 \mathrm{wt} \%$; Table 1), it is clear that any addition of mantle peridotites $\left(\mathrm{SiO}_{2}=44.6 \mathrm{wt} \%\right.$; Table 1) and/ or quartzites $\left(\mathrm{SiO}_{2}=97.6 \mathrm{wt} \%\right.$; Table 1) shifts the composition to higher $\mathrm{SiO}_{2}$-values in the classification diagrams (Fig. 6a). Therefore, based on the observed mineral assemblage (clinopyroxene, olivine, amphibole, phlogopite with abundant melilite) than rather on the primitive mineral chemistry, we argue that the original composition of the magma was olivine melilititic in composition. The increased $\mathrm{CaO}$ content in the augitic Type $1 \mathrm{~b}$ rims and the occasional occurrences of the $\mathrm{CaO}$-rich rims around the peridotitic olivines also points to a $\mathrm{CaO}$-enriched magma composition (Electronic Appendix). This is again consistent with an olivine melilititic original magma at Finca la Nava.

Although slightly contaminated by accidental lithics, there is still some important information that can be retrieved from the geochemistry of the hand-picked juvenile fraction. Due to the primitive character of the juvenile material (\#Mg ranges between 75.4 and 79.5; Table 1), it is unlikely that the Finca la Nava magma underwent significant fractional crystallization en route to the surface. Instead, the \#Mg is similar what would be expected from near-primary mantlederived basaltic or melilititic magmas (Green et al. 1974; Brooker et al. 2001). For a mantle-derived magma, the rather low $\mathrm{K}$ content in the juvenile material (Fig. 7a) indicates the presence of a residual K-bearing phase (e.g. phlogopite or amphibole) in the mantle source. In general, higher ratios of $\mathrm{Rb} / \mathrm{Sr}$ and lower $\mathrm{Ba} / \mathrm{Rb}$ ratios are indicative of phlogopite, whereas the opposite is true if the source contains amphibole (LaTourrette et al. 1995; Furman and Graham 1999). The FIN magmas have $\mathrm{Rb} / \mathrm{Sr}$ ratios ranging between 0.05 and 0.11 , whereas the $\mathrm{Ba} / \mathrm{Rb}$ ratio varies between 12.7 and 26.4 indicating amphibole in the source region (Electronic Appendix). However, the samples with the highest $\mathrm{Rb} / \mathrm{Sr}$ ratios also have the lowest $\mathrm{Ba} / \mathrm{Rb}$ ratios, which also points to the presence of phlogopite in the source. This is consistent with previous reports of a metasomatized mantle source (containing both amphibole and phlogopite) underlying the CVP (Bianchini et al. 2010; Villaseca et al. 2010). 
Table 2 LOI corrected major (wt\%) and trace element ( $\mathrm{ppm}$ ) analysis of the bulk rock samples with increasing height from Finca la Nava maar

\begin{tabular}{|c|c|c|c|c|c|c|c|c|c|c|c|c|c|}
\hline \multirow{2}{*}{$\begin{array}{l}\text { Location } \\
\text { Sample }\end{array}$} & \multicolumn{13}{|c|}{ Lower outcrop } \\
\hline & $6 \mathrm{~m}$ & 61 & $6 \mathrm{k}$ & $6 j$ & $6 \mathrm{i}$ & $6 \mathrm{~h}$ & $6 \mathrm{~g}$ & $6 f$ & $6 e$ & $6 \mathrm{~d}$ & $6 c$ & $6 b$ & $6 a$ \\
\hline $\mathrm{SiO}_{2}(\mathrm{wt} \%)$ & 73.0 & 65.6 & 70.5 & 70.6 & 66.1 & 64.6 & 69.9 & 71.8 & 61.3 & 72.0 & 69.9 & 65.8 & 72.4 \\
\hline $\mathrm{TiO}_{2}$ & 1.5 & 1.9 & 1.7 & 1.6 & 1.2 & 1.8 & 1.5 & 1.4 & 1.5 & 1.3 & 1.6 & 1.4 & 1.3 \\
\hline $\mathrm{Al}_{2} \mathrm{O}_{3}$ & 6.9 & 7.7 & 7.4 & 7.1 & 5.2 & 7.0 & 6.6 & 6.0 & 5.8 & 6.0 & 7.1 & 6.0 & 5.5 \\
\hline $\mathrm{Fe}_{2} \mathrm{O}_{3}$ & 5.4 & 6.6 & 5.9 & 6.0 & 6.1 & 7.0 & 5.8 & 5.9 & 6.3 & 5.7 & 6.5 & 6.6 & 5.4 \\
\hline $\mathrm{MnO}$ & 0.1 & 0.1 & 0.1 & 0.1 & 0.1 & 0.1 & 0.1 & 0.1 & 0.1 & 0.1 & 0.1 & 0.1 & 0.1 \\
\hline $\mathrm{MgO}$ & 6.0 & 7.4 & 6.8 & 7.4 & 13.7 & 9.2 & 7.3 & 7.6 & 9.4 & 8.5 & 7.7 & 8.9 & 7.7 \\
\hline $\mathrm{CaO}$ & 5.1 & 8.1 & 5.3 & 5.3 & 6.4 & 8.2 & 6.7 & 5.4 & 13.2 & 5.0 & 5.2 & 9.4 & 6.1 \\
\hline $\mathrm{Na}_{2} \mathrm{O}$ & 0.1 & 0.1 & 0.1 & 0.1 & 0.1 & 0.1 & 0.1 & 0.1 & 0.1 & 0.2 & 0.1 & 0.1 & 0.2 \\
\hline $\mathrm{K}_{2} \mathrm{O}$ & 1.6 & 1.7 & 1.5 & 1.5 & 0.7 & 1.4 & 1.3 & 1.1 & 0.9 & 0.9 & 1.3 & 0.9 & 0.9 \\
\hline $\mathrm{P}_{2} \mathrm{O}_{5}$ & 0.4 & 0.5 & 0.5 & 0.4 & 0.3 & 0.5 & 0.4 & 0.4 & 0.4 & 0.4 & 0.6 & 0.4 & 0.4 \\
\hline Total: & 99.9 & 99.7 & 99.8 & 100.0 & 100.0 & 99.8 & 99.7 & 99.8 & 99.3 & 100.0 & 99.9 & 99.7 & 100.0 \\
\hline$\# \mathrm{Mg}$ & 69.0 & 69.1 & 69.6 & 70.9 & 81.6 & 72.2 & 71.3 & 72.0 & 74.8 & 74.7 & 70.1 & 72.8 & 73.9 \\
\hline $\mathrm{Sc}(\mathrm{ppm})$ & 16.3 & 16.1 & 14.1 & 17.2 & 17.4 & 18.4 & 15.4 & 13.3 & 15.9 & 13.3 & 14.3 & 15.4 & 16.1 \\
\hline V & 111.3 & 104.9 & 101.4 & 110.3 & 114.4 & 117.8 & 105.6 & 93.2 & 108.5 & 106.5 & 118.6 & 113.7 & 109.1 \\
\hline $\mathrm{Cr}$ & 405.2 & 416.4 & 492.8 & 445.8 & 967.2 & 526.2 & 453.0 & 408.1 & 469.5 & 304.7 & 454.2 & 413.4 & 527.5 \\
\hline Co & 26.7 & 29.6 & 29.7 & 32.4 & 41.6 & 34.9 & 29.2 & 28.8 & 32.7 & 26.3 & 31.9 & 32.0 & 30.1 \\
\hline $\mathrm{Ni}$ & 169.1 & 178.7 & 481.3 & 217.7 & 512.7 & 290.7 & 299.8 & 236.8 & 264.7 & 199.7 & 250.3 & 228.8 & 239.3 \\
\hline $\mathrm{Cu}$ & 21.7 & 24.5 & 24.6 & 23.8 & 17.4 & 25.4 & 22.2 & 21.8 & 21.9 & 16.7 & 21.5 & 22.5 & 20.0 \\
\hline $\mathrm{Ga}$ & 12.8 & 11.0 & 10.7 & 12.2 & 7.7 & 12.5 & 11.3 & 9.7 & 8.8 & 8.2 & 9.6 & 11.7 & 9.1 \\
\hline $\mathrm{Rb}$ & 64.5 & 60.5 & 55.9 & 60.6 & 30.1 & 52.4 & 50.3 & 40.4 & 35.0 & 49.8 & 47.3 & 44.7 & 29.5 \\
\hline $\mathrm{Sr}$ & 369.3 & 443.7 & 440.9 & 541.8 & 356.7 & 724.2 & 535.0 & 387.4 & 408.8 & 315.8 & 444.8 & 616.9 & 413.0 \\
\hline $\mathrm{Y}$ & 22.2 & 17.8 & 16.2 & 20.7 & 11.8 & 20.3 & 20.5 & 14.6 & 15.7 & 17.4 & 17.4 & 18.2 & 18.2 \\
\hline $\mathrm{Zr}$ & 539.5 & 351.3 & 327.8 & 418.7 & 251.0 & 404.8 & 422.2 & 280.0 & 282.8 & 400.0 & 355.5 & 361.2 & 338.1 \\
\hline $\mathrm{Nb}$ & 42.7 & 44.5 & 42.4 & 46.6 & 27.6 & 51.8 & 46.2 & 34.7 & 40.5 & 36.3 & 42.1 & 44.9 & 38.5 \\
\hline Mo & 0.4 & 0.6 & 0.9 & 0.7 & 0.6 & 0.3 & 0.6 & 0.8 & 0.6 & 1.2 & 0.8 & 0.7 & 1.3 \\
\hline Cs & 1.2 & 1.1 & 1.1 & 1.0 & 0.5 & 0.7 & 0.8 & 0.7 & 0.6 & 0.9 & 1.1 & 1.1 & 1.4 \\
\hline $\mathrm{Ba}$ & 553.1 & 585.8 & 577.1 & 647.3 & 372.5 & 634.0 & 566.5 & 452.6 & 446.8 & 435.5 & 449.5 & 619.0 & 417.5 \\
\hline $\mathrm{La}$ & 48.1 & 43.6 & 40.4 & 49.4 & 28.0 & 51.3 & 49.8 & 35.4 & 38.5 & 40.9 & 42.0 & 44.8 & 37.3 \\
\hline $\mathrm{Ce}$ & 96.1 & 89.9 & 86.8 & 98.5 & 59.3 & 98.9 & 100.0 & 75.7 & 79.2 & 83.8 & 84.2 & 94.3 & 76.3 \\
\hline $\operatorname{Pr}$ & 10.6 & 9.9 & 9.4 & 10.8 & 6.5 & 11.1 & 10.6 & 8.3 & 9.0 & 9.1 & 9.3 & 10.7 & 8.3 \\
\hline $\mathrm{Nd}$ & 39.0 & 40.5 & 37.2 & 40.2 & 24.4 & 43.7 & 41.6 & 32.5 & 33.0 & 36.4 & 35.8 & 39.8 & 31.5 \\
\hline $\mathrm{Sm}$ & 8.0 & 6.8 & 7.3 & 7.3 & 4.5 & 7.7 & 7.5 & 6.3 & 6.0 & 6.6 & 6.8 & 7.4 & 6.0 \\
\hline $\mathrm{Eu}$ & 2.0 & 1.8 & 1.6 & 1.9 & 1.2 & 2.2 & 1.8 & 1.4 & 1.6 & 1.5 & 1.7 & 1.7 & 1.4 \\
\hline $\mathrm{Gd}$ & 6.5 & 5.5 & 5.0 & 6.2 & 3.4 & 6.2 & 6.4 & 4.2 & 4.8 & 5.3 & 5.2 & 5.2 & 5.0 \\
\hline $\mathrm{Tb}$ & 0.7 & 0.6 & 0.7 & 0.8 & 0.5 & 0.8 & 0.8 & 0.6 & 0.6 & 0.8 & 0.7 & 0.8 & 0.6 \\
\hline Dy & 4.4 & 3.8 & 3.5 & 4.1 & 2.4 & 4.3 & 4.0 & 3.4 & 3.4 & 3.6 & 3.6 & 4.0 & 3.2 \\
\hline Ho & 0.7 & 0.6 & 0.6 & 0.7 & 0.5 & 0.8 & 0.7 & 0.5 & 0.5 & 0.6 & 0.6 & 0.7 & 0.6 \\
\hline $\mathrm{Er}$ & 2.0 & 1.6 & 1.5 & 1.9 & 1.3 & 2.0 & 1.7 & 1.7 & 1.5 & 2.1 & 1.7 & 1.9 & 1.6 \\
\hline $\mathrm{Tm}$ & 0.3 & 0.2 & 0.2 & 0.3 & 0.1 & 0.3 & 0.2 & 0.2 & 0.1 & 0.2 & 0.2 & 0.2 & 0.2 \\
\hline $\mathrm{Yb}$ & 1.9 & 1.8 & 1.5 & 1.7 & 1.2 & 1.5 & 1.7 & 1.4 & 1.3 & 1.9 & 1.2 & 1.3 & 1.4 \\
\hline $\mathrm{Lu}$ & 0.3 & 0.2 & 0.2 & 0.2 & 0.2 & 0.2 & 0.2 & 0.2 & 0.2 & 0.3 & 0.2 & 0.3 & 0.2 \\
\hline $\mathrm{Hf}$ & 13.1 & 8.0 & 7.7 & 9.2 & 6.3 & 9.1 & 10.1 & 7.0 & 7.2 & 9.4 & 8.3 & 9.0 & 7.7 \\
\hline $\mathrm{Ta}$ & 2.5 & 2.7 & 2.3 & 2.7 & 1.6 & 2.8 & 2.6 & 1.7 & 2.4 & 2.0 & 2.4 & 2.6 & 2.0 \\
\hline $\mathrm{Pb}$ & 4.0 & 3.5 & 4.4 & 3.7 & 3.0 & 3.5 & 3.9 & 3.2 & 2.6 & 3.1 & 2.9 & 4.0 & 5.8 \\
\hline Th & 11.6 & 8.7 & 8.3 & 10.5 & 5.8 & 10.1 & 10.2 & 6.5 & 6.9 & 9.3 & 8.7 & 9.6 & 9.3 \\
\hline $\mathrm{U}$ & 2.5 & 1.8 & 1.9 & 2.3 & 1.3 & 2.2 & 2.0 & 1.6 & 1.5 & 2.0 & 1.8 & 2.2 & 2.1 \\
\hline
\end{tabular}


Table 2 continued

\begin{tabular}{|c|c|c|c|c|c|c|c|c|c|c|c|c|c|c|c|}
\hline \multirow{2}{*}{$\begin{array}{l}\text { Location } \\
\text { Sample }\end{array}$} & \multicolumn{15}{|c|}{ Upper outcrop } \\
\hline & $3 p$ & 30 & $3 n$ & $3 m$ & $3 \mathrm{k}$ & $3 \mathrm{j}$ & $3 i$ & $3 \mathrm{~h}$ & $3 g$ & $3 f$ & $3 e$ & $3 d$ & $3 c$ & $3 b$ & $3 a$ \\
\hline $\mathrm{SiO}_{2}(\mathrm{wt} \%)$ & 73.3 & 70.4 & 77.2 & 68.9 & 66.0 & 72.9 & 73.8 & 77.2 & 73.9 & 71.9 & 64.5 & 70.5 & 80.0 & 69.6 & 72.7 \\
\hline $\mathrm{TiO}_{2}$ & 1.0 & 1.2 & 1.0 & 1.2 & 1.0 & 1.0 & 0.9 & 0.8 & 1.1 & 1.2 & 1.3 & 1.1 & 0.9 & 1.3 & 1.2 \\
\hline $\mathrm{Al}_{2} \mathrm{O}_{3}$ & 6.3 & 5.6 & 5.4 & 5.5 & 4.8 & 5.4 & 3.9 & 4.7 & 6.2 & 5.4 & 6.0 & 5.3 & 5.2 & 5.5 & 5.7 \\
\hline $\mathrm{Fe}_{2} \mathrm{O}_{3}$ & 5.0 & 5.2 & 4.2 & 5.2 & 5.8 & 5.0 & 4.0 & 3.9 & 4.5 & 4.9 & 6.8 & 5.2 & 3.6 & 5.5 & 5.2 \\
\hline $\mathrm{MnO}$ & 0.1 & 0.1 & 0.1 & 0.1 & 0.1 & 0.1 & 0.1 & 0.1 & 0.1 & 0.1 & 0.1 & 0.1 & 0.0 & 0.1 & 0.1 \\
\hline $\mathrm{MgO}$ & 8.5 & 8.1 & 6.2 & 8.3 & 13.9 & 8.6 & 7.1 & 7.7 & 7.4 & 7.7 & 13.3 & 10.0 & 5.0 & 9.0 & 8.2 \\
\hline $\mathrm{CaO}$ & 4.5 & 7.5 & 4.5 & 9.1 & 6.9 & 5.8 & 9.0 & 4.2 & 4.8 & 7.1 & 6.4 & 6.2 & 3.6 & 7.2 & 5.5 \\
\hline $\mathrm{Na}_{2} \mathrm{O}$ & 0.2 & 0.4 & 0.3 & 0.4 & 0.4 & 0.3 & 0.3 & 0.2 & 0.3 & 0.3 & 0.3 & 0.3 & 0.2 & 0.4 & 0.3 \\
\hline $\mathrm{K}_{2} \mathrm{O}$ & 1.1 & 1.0 & 0.9 & 0.8 & 0.6 & 0.8 & 0.6 & 0.7 & 1.2 & 0.8 & 0.8 & 0.8 & 0.9 & 0.9 & 0.9 \\
\hline $\mathrm{P}_{2} \mathrm{O}_{5}$ & 0.3 & 0.3 & 0.3 & 0.4 & 0.3 & 0.3 & 0.3 & 0.2 & 0.3 & 0.3 & 0.3 & 0.3 & 0.3 & 0.4 & 0.3 \\
\hline Total: & 100.2 & 99.8 & 100.0 & 99.8 & 99.9 & 100.2 & 99.8 & 99.6 & 99.9 & 99.9 & 99.9 & 99.9 & 99.8 & 99.8 & 100.0 \\
\hline$\# \mathrm{Mg}$ & 76.9 & 75.7 & 74.3 & 76.1 & 82.6 & 77.1 & 77.6 & 79.8 & 76.4 & 75.7 & 79.5 & 79.0 & 73.1 & 76.4 & 75.7 \\
\hline $\mathrm{Sc}(\mathrm{ppm})$ & 10.9 & 14.0 & 11.8 & 13.3 & 13.6 & 11.6 & 10.1 & 12.0 & 12.6 & 12.4 & 14.8 & 12.0 & 9.6 & 14.0 & 13.7 \\
\hline V & 82.9 & 102.9 & 85.3 & 92.8 & 105.5 & 89.6 & 76.6 & 78.8 & 98.1 & 94.1 & 108.1 & 92.3 & 68.4 & 111.7 & 87.9 \\
\hline $\mathrm{Cr}$ & 331.0 & 390.5 & 479.1 & 387.0 & 953.2 & 564.3 & 334.5 & 524.2 & 376.7 & 399.4 & 704.7 & 551.7 & 280.8 & 458.0 & 457.1 \\
\hline Co & 22.5 & 26.0 & 27.4 & 26.1 & 41.6 & 27.5 & 24.2 & 28.3 & 24.5 & 25.1 & 41.1 & 32.3 & 16.9 & 28.4 & 28.6 \\
\hline $\mathrm{Ni}$ & 178.1 & 204.6 & 300.3 & 216.4 & 528.8 & 355.7 & 207.4 & 305.0 & 210.2 & 225.5 & 457.7 & 322.7 & 243.6 & 272.4 & 247.2 \\
\hline $\mathrm{Cu}$ & 13.5 & 15.4 & 15.2 & 18.8 & 18.2 & 15.4 & 11.5 & 13.6 & 16.0 & 17.9 & 20.0 & 16.8 & 12.5 & 20.1 & 18.1 \\
\hline $\mathrm{Ga}$ & 7.8 & 8.4 & 8.8 & 8.1 & 7.4 & 8.2 & 5.3 & 7.7 & 8.8 & 7.9 & 9.7 & 7.8 & 7.1 & 8.5 & 8.8 \\
\hline $\mathrm{Rb}$ & 38.7 & 42.9 & 42.7 & 46.1 & 31.7 & 39.1 & 29.0 & 31.8 & 52.2 & 45.7 & 35.9 & 35.9 & 35.5 & 46.0 & 33.0 \\
\hline $\mathrm{Sr}$ & 221.9 & 310.6 & 218.4 & 318.2 & 223.6 & 269.1 & 238.2 & 159.6 & 219.0 & 271.5 & 244.0 & 241.5 & 212.3 & 296.6 & 228.5 \\
\hline $\mathrm{Y}$ & 14.4 & 16.3 & 15.2 & 15.8 & 12.1 & 17.6 & 11.8 & 15.2 & 17.5 & 14.7 & 15.3 & 14.1 & 15.5 & 16.6 & 15.6 \\
\hline $\mathrm{Zr}$ & 389.5 & 357.7 & 333.2 & 341.7 & 247.7 & 359.1 & 301.8 & 428.2 & 416.3 & 332.7 & 298.6 & 323.7 & 460.5 & 355.0 & 377.8 \\
\hline $\mathrm{Nb}$ & 25.4 & 33.3 & 25.5 & 30.4 & 26.4 & 26.2 & 23.2 & 23.3 & 30.0 & 31.3 & 33.3 & 28.7 & 21.2 & 35.0 & 32.1 \\
\hline Mo & 1.8 & 1.3 & 1.1 & 0.8 & 1.3 & 1.3 & 3.1 & 2.8 & 0.7 & 1.0 & 0.9 & 2.3 & 1.0 & 1.0 & 2.1 \\
\hline Cs & 0.8 & 0.8 & 0.8 & 0.8 & 0.6 & 0.7 & 0.4 & 0.6 & 0.9 & 0.9 & 0.7 & 0.7 & 0.7 & 0.9 & 0.8 \\
\hline $\mathrm{Ba}$ & 380.1 & 452.4 & 389.4 & 412.8 & 294.6 & 524.9 & 303.7 & 325.1 & 466.7 & 413.8 & 448.8 & 412.2 & 340.8 & 483.4 & 443.2 \\
\hline $\mathrm{La}$ & 34.0 & 36.4 & 30.3 & 34.3 & 27.6 & 32.4 & 26.7 & 43.2 & 42.4 & 34.0 & 37.8 & 36.0 & 35.0 & 37.8 & 36.8 \\
\hline $\mathrm{Ce}$ & 71.7 & 75.7 & 61.9 & 67.5 & 58.2 & 70.8 & 54.5 & 87.3 & 90.0 & 71.2 & 81.0 & 74.5 & 69.6 & 77.9 & 77.2 \\
\hline $\operatorname{Pr}$ & 8.0 & 8.3 & 6.6 & 7.6 & 6.3 & 8.3 & 5.9 & 9.1 & 9.8 & 7.8 & 8.8 & 7.9 & 7.1 & 8.6 & 8.4 \\
\hline $\mathrm{Nd}$ & 28.6 & 32.7 & 26.6 & 30.5 & 24.3 & 37.6 & 22.8 & 33.3 & 36.4 & 30.6 & 33.2 & 30.1 & 27.9 & 33.8 & 33.1 \\
\hline $\mathrm{Sm}$ & 4.8 & 5.9 & 5.0 & 5.6 & 4.0 & 8.0 & 3.9 & 4.8 & 5.7 & 5.5 & 5.2 & 5.2 & 5.2 & 5.4 & 5.5 \\
\hline $\mathrm{Eu}$ & 1.1 & 1.4 & 1.0 & 1.2 & 1.1 & 1.6 & 1.1 & 1.1 & 1.5 & 1.4 & 1.6 & 1.3 & 1.0 & 1.6 & 1.4 \\
\hline $\mathrm{Gd}$ & 3.8 & 4.0 & 3.6 & 4.2 & 3.2 & 5.4 & 3.7 & 4.1 & 5.1 & 3.6 & 4.7 & 4.0 & 3.4 & 4.6 & 4.5 \\
\hline $\mathrm{Tb}$ & 0.6 & 0.6 & 0.6 & 0.6 & 0.5 & 0.7 & 0.4 & 0.6 & 0.6 & 0.5 & 0.5 & 0.6 & 0.6 & 0.6 & 0.5 \\
\hline Dy & 2.9 & 3.6 & 2.7 & 3.0 & 2.7 & 3.8 & 2.6 & 2.8 & 3.6 & 2.9 & 3.1 & 2.9 & 3.0 & 3.3 & 3.4 \\
\hline Ho & 0.4 & 0.5 & 0.5 & 0.5 & 0.5 & 0.7 & 0.4 & 0.5 & 0.7 & 0.6 & 0.6 & 0.5 & 0.5 & 0.6 & 0.5 \\
\hline $\mathrm{Er}$ & 1.8 & 1.8 & 1.6 & 1.6 & 1.4 & 1.7 & 1.1 & 1.9 & 2.0 & 1.4 & 1.6 & 1.3 & 1.7 & 1.6 & 1.8 \\
\hline $\mathrm{Tm}$ & 0.2 & 0.2 & 0.2 & 0.1 & 0.1 & 0.3 & 0.2 & 0.2 & 0.2 & 0.2 & 0.2 & 0.1 & 0.2 & 0.2 & 0.2 \\
\hline $\mathrm{Yb}$ & 1.5 & 1.7 & 1.5 & 1.5 & 0.8 & 1.8 & 0.6 & 1.3 & 1.2 & 1.8 & 1.6 & 1.4 & 1.6 & 0.9 & 1.6 \\
\hline $\mathrm{Lu}$ & 0.2 & 0.2 & 0.2 & 0.2 & 0.2 & 0.3 & 0.2 & 0.3 & 0.2 & 0.2 & 0.3 & 0.2 & 0.2 & 0.2 & 0.2 \\
\hline Hf & 9.4 & 8.2 & 7.8 & 7.9 & 5.8 & 8.8 & 7.0 & 10.7 & 10.7 & 7.5 & 6.9 & 7.8 & 11.3 & 8.5 & 9.1 \\
\hline $\mathrm{Ta}$ & 1.4 & 1.9 & 1.5 & 1.9 & 1.6 & 1.5 & 1.4 & 1.4 & 1.8 & 1.8 & 2.1 & 1.7 & 1.3 & 2.1 & 1.9 \\
\hline $\mathrm{Pb}$ & 3.1 & 2.5 & 3.0 & 2.6 & 2.4 & 3.3 & 2.3 & 3.1 & 3.5 & 3.1 & 3.2 & 2.7 & 2.9 & 3.5 & 3.5 \\
\hline Th & 7.7 & 8.4 & 7.7 & 7.8 & 5.6 & 7.6 & 6.0 & 8.0 & 9.6 & 7.3 & 6.7 & 7.1 & 9.2 & 8.0 & 8.3 \\
\hline $\mathrm{U}$ & 1.7 & 2.0 & 1.5 & 1.7 & 1.4 & 2.0 & 1.4 & 1.7 & 2.1 & 1.7 & 1.4 & 1.8 & 1.9 & 1.8 & 1.7 \\
\hline
\end{tabular}



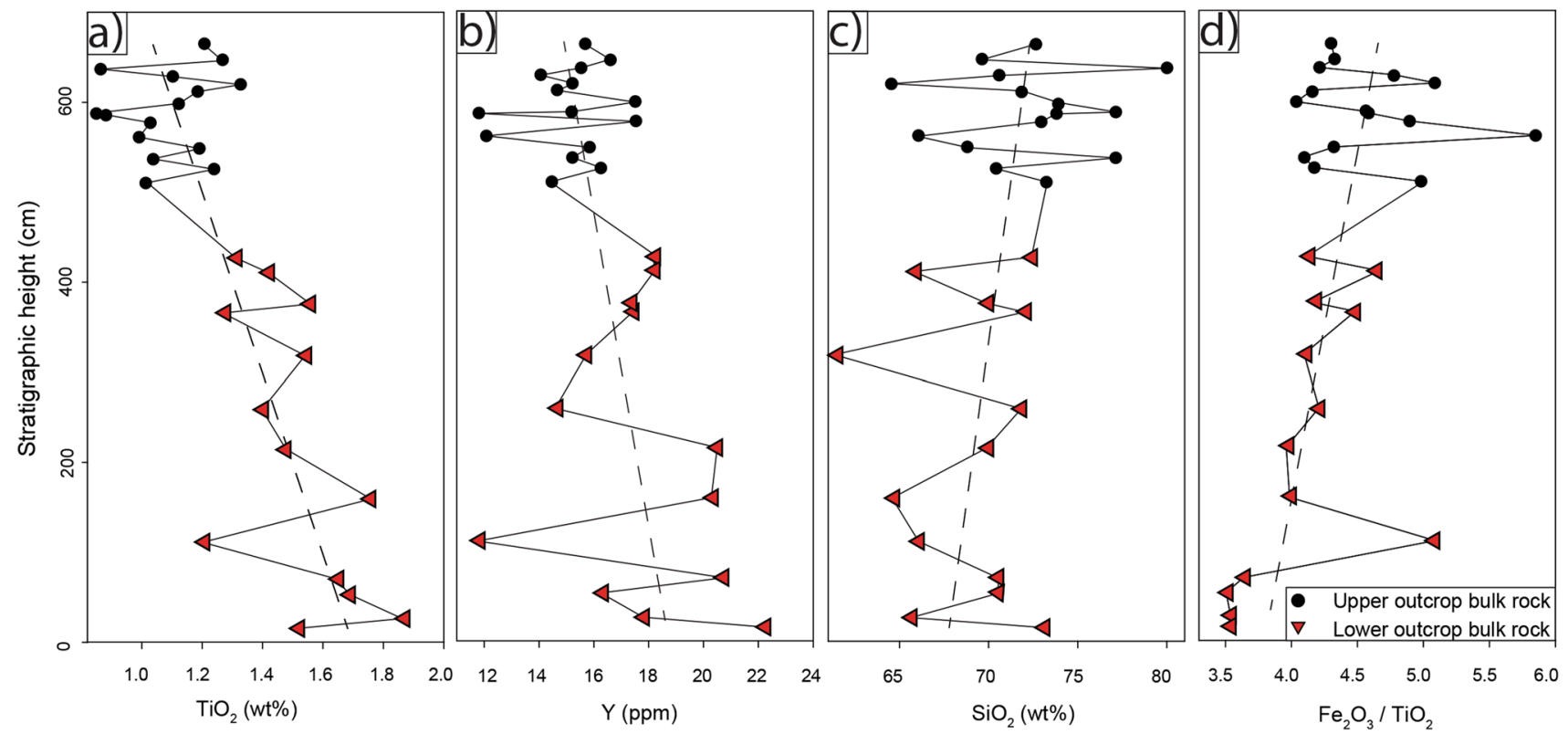

Fig. 8 Representative stratigraphic height variation diagrams for representative elements with $\mathbf{a} \mathrm{TiO}_{2}$ and $\mathbf{b} \mathrm{Y}$ showing a negative trend, whereas c $\mathrm{SiO}_{2}$ and $\mathbf{d} \mathrm{Fe}_{2} \mathrm{O}_{3} / \mathrm{TiO}_{2}$ have a positive trend

In terms of the degree of mantle melting, we plotted the FIN juvenile material using two separate models. In the first (Fig. 9a), we plotted Sm/Y versus La/Sm (based on Mana et al. (2012) and Mattsson et al. (2013)), and in the second model (Fig. 9b), we plotted $\mathrm{Ce} / \mathrm{Y}$ versus $\mathrm{Zr} / \mathrm{Nb}$ (based on Hardarson and Fitton (1991) and MacDonald et al. (2001)). Independent of which of these models we apply, the juvenile FIN material gives clear and coherent results indicating formation by a very small degree of melting $(<2 \%$; Fig. 9a, b) of a garnet-bearing source. From experimental petrology studies, we can then place this garnet-bearing source at approximately $75-90 \mathrm{~km}$ depth beneath Finca la Nava (Wyllie and Huang 1976; Lee et al. 2000).

\section{Magma ascent and incorporation of mantle xenoliths and upper-crustal lithics}

From the point when the FlN magma separated from its garnet-bearing source, it must have ascended rapidly through the lithosphere in order to keep the mantle xenoliths entrained within the rising magma. Already, the appearance of mantle xenoliths points to a fast ascending magma (Jordan et al. 2014). A simple minimum ascent rate for the FIN magma can be calculated from the settling velocity $\left(V_{\mathrm{s}}\right)$ of the mantle xenoliths. $V_{\mathrm{s}}$ is determined by the following equation (Sparks et al. 2006):

$V_{s}=C_{d}\left(\frac{\Delta \alpha g d}{\alpha}\right)^{\frac{1}{2}}$ where $C_{\mathrm{d}}$ is the drag coefficient that is taken as 1 [order of unity; (Sparks et al. 2006; Mattsson 2012)], $\alpha$ is the magma density in $\mathrm{kg} \mathrm{m}^{-3}, \Delta \alpha$ is the density contrast between the magma and the mantle xenoliths in $\mathrm{kg} \mathrm{m}^{-3}$, $\mathrm{g}$ is the acceleration of gravity in $\mathrm{m} \mathrm{s}^{-2}$ and $\mathrm{d}$ is the diameter of the xenolith in $\mathrm{m}$. The density of the mantle peridotites was calculated by measuring the volume, using a He-pycnometer, divided by the weight. The resulting value of $3320 \mathrm{~kg} \mathrm{~m}^{-3}$ is relatively low, but it can be assumed that this is linked to the metasomatic overprint, which is a very common feature in the CVP (Bianchini et al. 2010; Villaseca et al. 2010). The measured density is also in agreement with similar findings from the Pello Hill scoria cone in the East African Rift Valley where metasomatic veins were found in the mantle xenoliths leading to relatively low densities (Dawson and Smith 1988). The density of an olivine melilititic/nephelinitic melt is approximately $2650 \pm 30 \mathrm{~kg} \mathrm{~m}^{-3}$ (Spera and Bergman 1980; Lange and Carmichael 1990), resulting in a $\Delta \alpha$-value of 640 to $700 \mathrm{~kg} \mathrm{~m}^{-3}$.

The largest found mantle xenolith at Finca la Nava measures $0.26 \mathrm{~m}$ in diameter $(d=0.26 \mathrm{~m})$, and thus, solving Eq. 1 gives a minimum ascent rate of $\sim 0.80 \mathrm{~m} \mathrm{~s}^{-1}$. This result is in a good agreement with other studies of various silica-undersaturated magmas (Spera 1984; Klügel et al. 1997; Demouchy et al. 2006; Sparks et al. 2006; Mattsson 2012; Berghuijs and Mattsson 2013). This suggests that the magma may have reached the surface within $24 \mathrm{~h}$ from leaving the source region in the upper subcontinental lithosphere. The amount and the size of the mantle xenoliths are larger in the lower outcrop, which shows that also the 


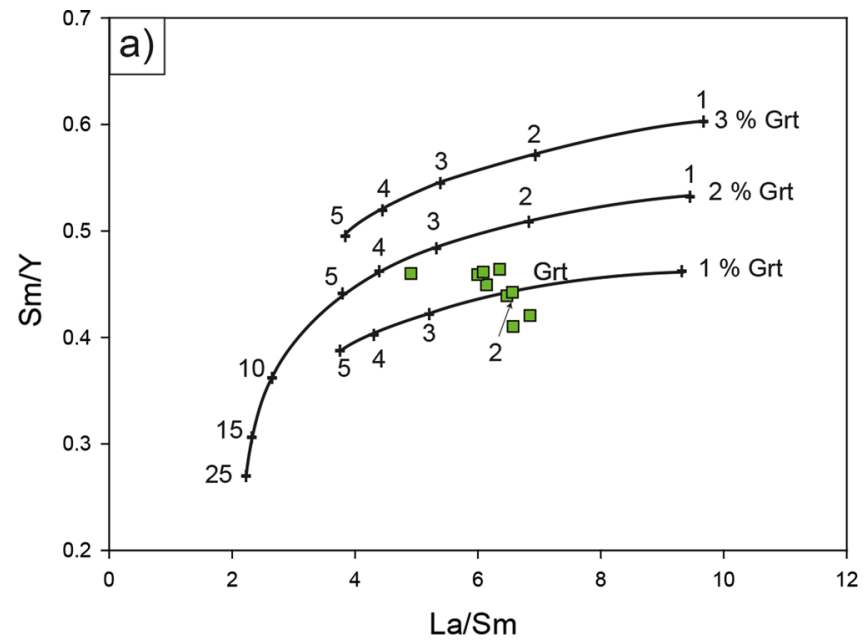

Fig. 9 Various trace element modelling of the source for the handpicked juvenile fragments from Finca la Nava. a Modelling of primary mantle melting using $\mathrm{Sm} / \mathrm{Y}$ versus $\mathrm{La} / \mathrm{Sm}$. Numbers in italics indicate the percentage of melting required. The partial melting was modelled based on the same mineral phase mode as that used by Mana et al. (2012) for the Essimingor volcano in northern Tanzania, that is olivine $60 \%$, clinopyroxene $16 \%$, orthopyroxene $16 \%$, phlogopite $5 \%$, amphibole $2 \%$ and garnet $1 \%$ (with garnet variation

magma ascent velocity was larger in the beginning of the eruption.

Disintegration of mantle peridotites into the juvenile olivine melilititic FIN magma, in combination with rapid decompression (ascent), probably resulted in the observed disequilibrium features and the Type $1 \mathrm{~b}$ clinopyroxene overgrowth rims (Fig. 4c). Blundy and Cashman (2005) argued that rapid decompression-driven crystal growth can occur within days or month in a silica-rich system, producing overgrowth rims on pre-existing crystals. However, our calculations of ascent rate for the Finca la Nava magma imply that the rim growth must have been extremely rapid. Unfortunately, there are no studies (at least to our knowledge) that have focused on crystallization rates for volatile-rich, silicaundersaturated, systems like that of Finca la Nava (with abundant amphibole and phlogopite, in addition to the high $\mathrm{CO}_{2}$-solubility). Therefore, we suspect that the overgrowth rims may be produced extremely rapidly in volatile-rich systems as that of olivine melilitites. In addition to the high $\mathrm{CO}_{2}$ solubility of melilititic magmas (Brooker et al. 2001), breakdown of phlogopite as seen in thin sections [rounded to resorbed shapes, similar to that reported by Berghuijs and Mattsson (2013)] may also have expelled additional volatiles to the rising magma during decompression (i.e. ascent).

\section{Fragmentation processes and pyroclast morphologies}

One of the main questions that arises, considering the olivine melilititic composition of the Finca la Nava magma,

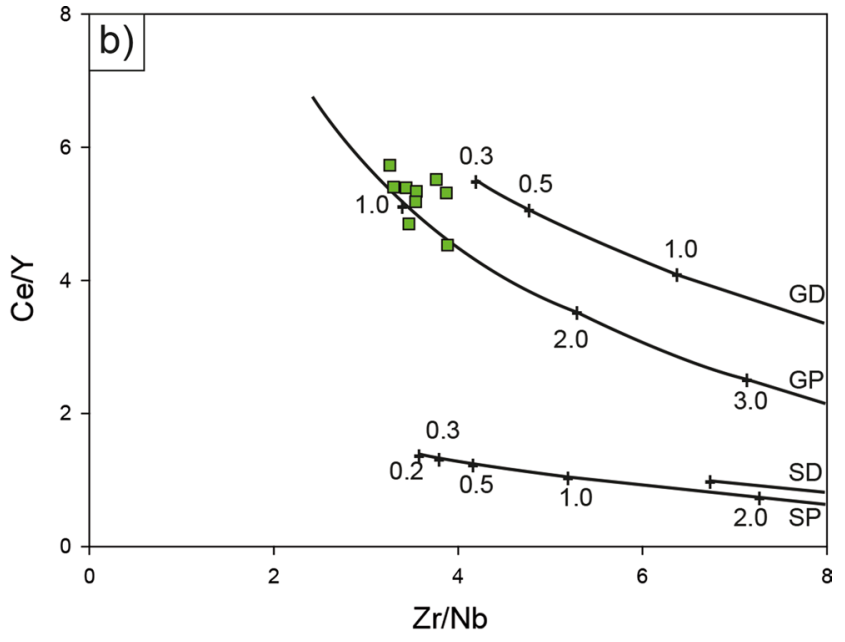

balanced by the olivine content at 1,2 and $3 \%$ ). Note that the two models applied here to the Finca la Nava magma both indicate a low degree of partial melting $(<2 \%)$ of a garnet-bearing source. b Partial melting model (MacDonald et al. 2001) including lines with number indicating melt percentages are non-modal melting curves from Hardarson and Fitton (1991). GP and GD are primitive versus depleted garnet lherzolite, and SP and SD corresponds to primitive versus depleted spinel peridotite

is whether the fragmentation was dominated by interactions with an external water source (phreatomagmatic) or if it was driven by exsolution of volatiles (magmatic). Most maar-forming models invoke phreatomagmatic fragmentation (McBirney 1963; Lorenz 1975, 1986; Nixon 1995; White 1996; Kurszlaukis et al. 1998; Wohletz and Zimanowski 2000; Lorenz and Kurszlaukis 2007; Valentine and White 2012). However, several authors have also advocated magmatic fragmentation especially for eruptions involving silica-undersaturated, $\mathrm{CO}_{2}$-rich, magmas such as that erupted at Finca la Nava (Clement 1982; Stoppa 1996; Field and Scott Smith 1998; Sparks et al. 2006; Wilson and Head III 2007; Cas et al. 2008; Mattsson and Tripoli 2011; Berghuijs and Mattsson 2013).

Typically, the sub-rounded to spherical pyroclast morphologies, which are present in many silica-undersaturated eruptions, are in stark contrast to the typical blocky/equant morphologies commonly associated with phreatomagmatic fragmentation (Wohletz 1983; Dellino et al. 2001). Although studies of phreatomagmatic eruptions (and also experiments) have shown that ductile fragmentation can occur (Zimanowski et al. 1991; Büttner et al. 2002; Solgevik et al. 2007), it is unlikely that they could produce deposits consisting almost exclusively of sub-rounded pyroclasts for all grain sizes. On the other hand, many of the inferred magmatic maar deposits are depleted in the fine fractions (Mattsson and Tripoli 2011; Berghuijs and Mattsson 2013), whereas typical phreatomagmatic deposits are rich in these size fractions (Walker 1971, 1981; Zimanowski et al. 1991). 
In thin section, nearly all juvenile pyroclasts from Finca la Nava exhibit an outer rim with low vesicularity with a systematic increase in the bubble size towards the centre (Fig. 10a, b). The overall textures of our samples bear strong resemblance to the pyroclasts produced in fountaining-episodes of the Kilauea Iki 1959 eruption, where the bubble population in the interior of the juvenile pyroclasts has evolved via a combination of coalescence and continued bubble growth after fragmentation and quenching of the outer rim (Stovall et al. 2011). Coating of accidental lithics is also common in this type of volcanic eruptions as melt is readily available for coating. However, the presence of sub-rounded pyroclasts does not necessarily require magmatic fragmentation as secondary processes can also significantly affect the particle shape. Milling/abrasion of the outer surfaces of irregular-shaped juvenile fragments is one possible explanation. This could be achieved in the vent and/or conduit by collisions with other juvenile particles and/or accidental lithics (Dufek and Manga 2008). Kueppers et al. (2012) showed experimentally that the amount of abrasion (and generation of fine ash) is strongly dependent on the porosity of the sample. Pyroclasts from Finca la Nava range in vesicularity between 5 and $45 \%$, much of this is due to post-fragmentation bubble growth and coalescence (Fig. 10). Therefore, at the time when the pyroclasts were entrained within a collisional regime, we can assume that the vesicularity was around 5-20\%. From the experiments, we know that porosities of up to $20.5 \%$ produce a maximum mass fraction of $3.5 \%$ fine ash after $2 \mathrm{~h}$ of abrasion (Kueppers et al. 2012). Although the material used in the experimental study had a different starting grain size distribution, chemical composition and crystallinity (i.e. Unzen dacite) than our samples, some conclusions can be drawn. The experiments show that it would be close to impossible to produce rounded pyroclasts by abrasion alone without significant production of very fine ash-fractions. At FlN, the amount of fine-grained material differs significantly between the lower and upper outcrop ( $<4$ and $<0.3 \mathrm{wt} \%$, respectively, for the $<125 \mu \mathrm{m}$ fraction), yet all juvenile pyroclasts in both outcrops are equally round. This strongly indicates that abrasion alone cannot explain the rounding of the pyroclasts as we would expect also roughly the same amount of fine ash to be present in both outcrops. In addition to this, we would also expect this abrasion to affect the accidental lithics in a similar way. The hardness of the lithics and juvenile fractions may differ, but there are abundant small quartzite fragments that must have collided with each other in such a case. However, all quartzitic fragments are angular, independent of grain size, at the Finca la Nava maar.

Recycling of material in the vent region may also change the morphology of the pyroclasts (Houghton and Smith 1993; Ross and White 2012; Lefebvre et al. 2013).
Recycling into the vent could be the result of simple fallback from a plume, or by collapse and recycling of material from the crater rim as it progressively widens and subsides. Independent on which of these scenarios brings material back into the vent region, the result will be coating by a new melt (Carracedo Sánchez et al. 2009) and/or adhering smaller-sized particles (Houghton and Smith 1993) to the outer surface of previously fragmented material, which results in progressive rounding of pyroclasts over time. Some of the fragments at FIN indeed show characteristics like this, but they are relatively rare $(\ll 5 \%)$, so that we do not believe that fallback and within-vent recycling was the main reason for the rounding of the bulk of the pyroclasts studied here.

There is also no depositional evidence present, which is commonly used to infer phreatomagmatic fragmentation [such as plastering against obstacles, accretionary lapilli and vesiculated tuffs (Lorenz 1974; Cole et al. 2001; Solgevik et al. 2007)]. In combination, all but one of the above-listed characteristics indicate a dominance of magmatic fragmentation at Finca la Nava (i.e. the high amount of fine-grained ash in the lower outcrop). This large portion of fine ash in the lower outcrop (Electronic Appendix) with approximately $4 \mathrm{wt} \%$ of very fine ash is inconsistent with most magmatic $\mathrm{SiO}_{2}$-undersaturated maars (Berghuijs and Mattsson 2013) and more in line with a phreatomagmatic origin (Walker 1971; Wohletz 1983). Thus, because there are some indications for both types of fragmentation mechanisms operating at Finca la Nava, we cannot rule one out. They may also have been operating simultaneously as such phenomena have been previously observed at the Ukinrek maars in Alaska (Kienle et al. 1980), and in the Auckland Volcanic Field in New Zealand where "drying out" of the phreatomagmatic eruption occurred over time (Allen and Smith 1994; Houghton et al. 1999; Németh 2010; McGee et al. 2012).

\section{Growth of the Finca la Nava diatreme: insights from geochemistry and grain size distributions}

The observed compositional variation in the bulk rock samples as a function of stratigraphic height can be approximated by the main four components (juvenile material, quartzites, slates and mantle xenoliths). As shown in Fig. 8a, b, there is a clear decreasing trend with stratigraphic height recorded for $\mathrm{TiO}_{2}$ and $\mathrm{Y}$. Both elements can be used as proxies for the amount of juvenile material because these elements are essentially contributed to the bulk rock from the juvenile fraction (as seen in Table 1). Thus, we note a decrease in the relative proportions of juvenile material over time at Finca la Nava. This could represent (1) a true decrease in the amount of juvenile fragments erupted over time or (2) a dilution effect 
Fig. 10 a Photograph of a thin section showing a pyroclast (approx. $4.5 \mathrm{~mm}$ wide) with an outer rim with low vesicularity with a systematic increase in the bubble size towards the centre. b Digital tracing of (a) showing the distribution of crystals (red) and vesicles (white)
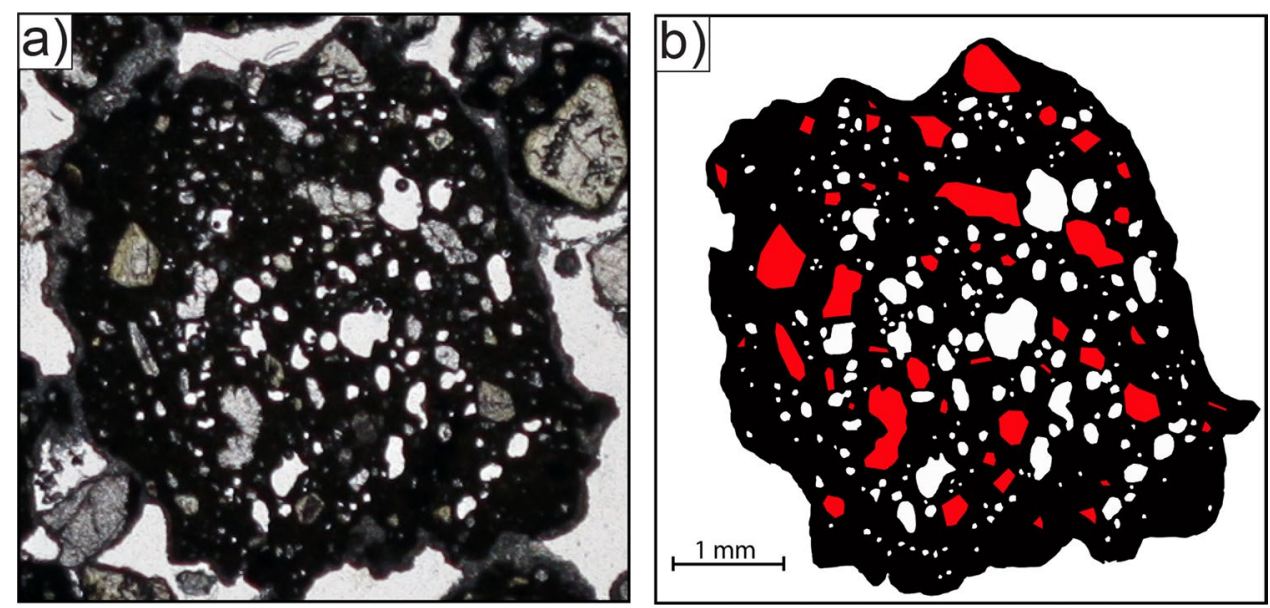

caused by the incorporation of one of the other lithologies. The increasing $\mathrm{SiO}_{2}$ content with stratigraphic height strongly indicates a dilution of the bulk rock composition by the quartzites (Fig. 8c). This is also supported by the field observations and the petrography, which both points to an increase in the overall size and abundance of quartzitic fragments with time (Fig. 2b, d). In addition to this, the amount of mantle xenoliths also increases with time as reflected by the $\mathrm{Fe}_{2} \mathrm{O}_{3}^{\mathrm{T}} / \mathrm{TiO}_{2}$ content of the bulk rock samples (Fig. 8d). This proxy is based on the fact that the mantle xenoliths are relatively high in $\mathrm{Fe}_{2} \mathrm{O}_{3}^{\mathrm{T}}$ and that the juvenile portion is rich in $\mathrm{TiO}_{2}$ but also in $\mathrm{Fe}_{2} \mathrm{O}_{3}^{\mathrm{T}}$ (Table 1). This means that low $\mathrm{Fe}_{2} \mathrm{O}_{3}^{\mathrm{T}} / \mathrm{TiO}_{2}$ ratios are indicative for significant contribution of juvenile material to the bulk rock and higher $\mathrm{Fe}_{2} \mathrm{O}_{3}^{\mathrm{T}} / \mathrm{TiO}_{2}$ ratios indicate the presence of mantle peridotites. The only and also proportional smallest component in the FIN maar are the slates, which show nearly no systematic chemical variation with stratigraphic height, but from the field observations we can say that the amount decreases with stratigraphic height. This implies that in the beginning of the eruption, the fragmentation level in the conduit could have been in contact with the slates (which perhaps also carried an aquifer to drive phreatomagmatic fragmentation). The dilution with $\mathrm{SiO}_{2}$ from the quartzitic fragments with increasing stratigraphic height allows for some important conclusion to be drawn on the process of diatreme formation at Finca la Nava. The relative increase of $\mathrm{SiO}_{2}$ shows that the amount of quartzites increased significantly as the eruption progressed, which was most likely achieved by slumping processes of large parts of the surrounding quartzites exposed on the surface. A hypothesis for diatreme formation can thus be put forward as follows (Fig. 11).

The very first explosions occurred relatively shallow (most likely close to a slate bearing layer as these are predominately included in the lowermost rim deposit). However, the exact depth of the initial explosions cannot be constrained, but it is likely that it started somewhere within the uppermost first hundred metres. This is supported by the fact that the contact to the quartzites and slates is outcropping in the close vicinity of the maar and can therefore not be very far beneath the crater itself. Secondly, recent experiments on fragmentation levels in phreatomagmatic eruptions show that most of the maarforming eruptions have their source region in depth of around $200 \mathrm{~m}$ or even shallower (Valentine et al. 2014). This is in line with other natural samples like the Hopi Buttes, USA (Lefebvre et al. 2013). The resulting ejecta contain a mix of all country rock lithologies, juvenile fragments and mantle xenoliths. The characteristics of these deposits, with few but large mantle xenoliths and a fine-grained character for the juvenile component, point to potential interaction with external water within the slates (Fig. 11). As the eruption continues, the overlying country rocks are successively excavated and the pressure at the point of fragmentation is lowered. This likely resulted in a shift in fragmentation level to deeper depths (Fig. 11), but there are no direct evidence to support or reject this interpretation. However, a deepening of the explosion foci would result in a widening of the crater and in slumping of the crustal basement and the previously formed pyroclastic deposits, which become recycled into the vent region (Lorenz 1986). This is a common feature in many maar-forming eruptions (Lorenz 1973; Self et al. 1980; Geshi et al. 2011), and it may lead to blocking of the vent region, which allows for pressure build-up (Lorenz 1971; Jordan et al. 2013). In some eruptions, blocking of the vent has been reported to cause a lateral movement of the vent (Sohn and Park 2005; Jordan et al. 2013). If this was the case at Finca la Nava, we would expect to see evidence for several vent-opening breccias, which are characterized by coarse lapilli and blocks as well as a high country rocks content (Solgevik et al. 2007; Jordan et al. 2013) but only one is reported from FIN (Stoppa 


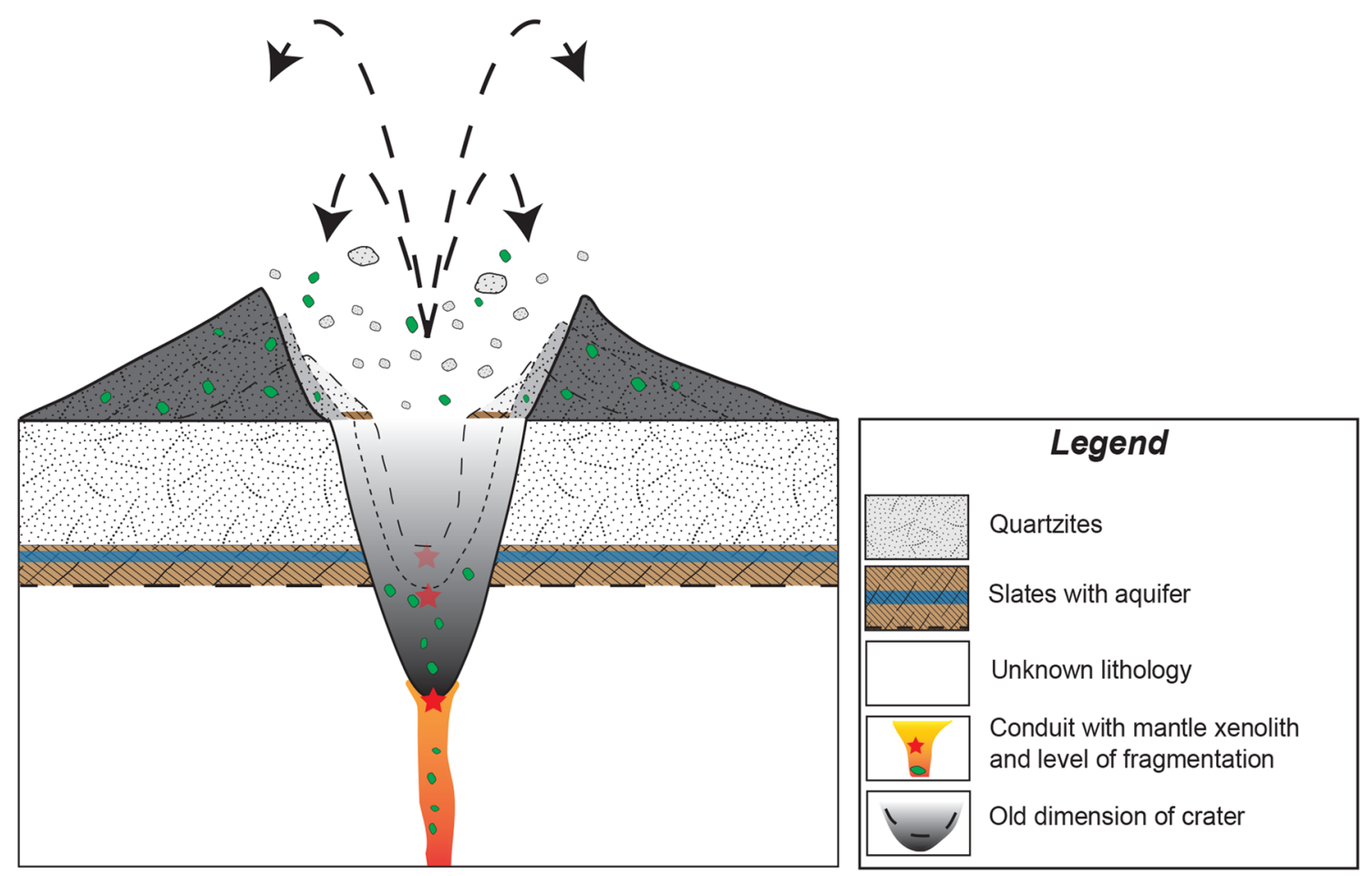

Fig. 11 Unscaled schematic model for the formation model of the FIN maar-diatreme deposits. The magma fragmentation level within the diatreme is penetrating to the deeper levels with time during the

et al. 2012). Additionally, we would expect to see unconformities in the ejecta rim as a direct result of the vents being located at different locations at different stages of the eruption. Both phenomena are not recorded at Finca la Nava. The morphology of the Finca la Nava maar is round shaped, which intuitively speaks for one vent but as pointed out by Jordan et al. (2013), the circular shape of a maar can also be the result of multiple vent locations. In summary, we cannot completely rule out vent migration at Finca la Nava due to the lack of measurable wellpreserved sedimentological features indicative of depositional direction (cross-bedding or bomb-sags) (Ort and Carrasco-Núñez 2009; Jordan et al. 2013).

Slumping of relatively large chunks of quartzite country rocks into the upper part of the infill (and the hardness of these) may explain the increase in the grain size of the bulk rock samples, as well as the increase in $\mathrm{SiO}_{2}$-content, with time during the eruption. In this hypothesis, we infer that most explosions where still ongoing at fairly deep levels of the diatreme, but once the pressure build-up allows ejecta to escape the infill, it also rips up and recycles the coarser quartzite fragments from the uppermost parts of the crater infill. The energy of these explosions are sufficient to eject the coarse-grained juvenile material, which was produced before by smaller explosions taking place in deeper parts eruption, which leads to enlargement of the crater in combination with slumping processes quartzitic basement and increased recycling

of the conduit/vent as suggested from experiments (Graettinger et al. 2014) and natural examples (Valentine and White 2012; Lefebvre et al. 2013).

The distribution of mantle xenoliths in the ejecta rim is also interesting. The bulk rock analyses as well as the stratigraphic profiles (Electronic Appendix) show that the total amount of mantle xenoliths increases with time during the eruption (Fig. 8d), whereas the size is larger in the lower section than in the upper ( 26 and $13 \mathrm{~cm}$, respectively). This indicates that the mantle xenoliths may have been carried in the magma in more or less equal amounts during the entire eruption and that the increase in total amount (and decrease in size) is a result of recycling of xenolith-bearing infill. This implies that the individual explosions must have been relatively vigorous throughout the eruption in order to carry the xenoliths to the surface and depositing them on the ejecta rim as well as in the infill. Although some material is clearly recycled in the vent region of Finca la Nava (e.g. slumping of already deposited rim material), it is clear that the total amount of recycling is most likely relatively small, which is also supported by the angular shape of the country rocks occurring together with sub-rounded juvenile pyroclasts. Thus, we conclude that both the chemical variations with stratigraphic height in the ejecta rim as well as the general upward coarsening of the deposit (Fig. 2, and 
Electronic Appendix) are consistent with this model for diatreme growth and evolution.

\section{Conclusions}

Geochemical analyses of handpicked juvenile material indicate that the olivine melilititic Finca la Nava magma formed by a small degree of melting $(<2 \%)$ of a garnetbearing source. Trace element ratios further indicate the presence of both phlogopite and amphibole in the source region, which fits well with a metasomatized mantle beneath the Calatrava Volcanic Province. From its source at $75-90 \mathrm{~km}$ depth, the magma must have risen quickly $\left(>0.8 \mathrm{~m} \mathrm{~s}^{-1}\right)$ as indicated by the abundant spinel-bearing mantle peridotites intermixed with juvenile material. Petrographic observations and mineral chemistry analyses also indicate that some of the mantle xenoliths and crustal lithics have disintegrated and can be found as xenocrysts in the juvenile magma. Bulk rock samples collected from a continuous sequence of the maar deposit show clear geochemical trends for many elements. An increase of $\mathrm{SiO}_{2}$ with increasing stratigraphic height, in combination with a decrease of the $\mathrm{Fe}_{2} \mathrm{O}_{3}^{\mathrm{T}} / \mathrm{TiO}_{2}$ ratio, suggests a dilution of the bulk rock by quartzites with time during the eruption. This is also supported by petrographic observations. We interpret this to reflect a deepening of the magma and country rock fragmentation level and of slumping processes of upper-crustal basement rocks (i.e. quartzites) into the vent area. Chunks of country rock slide into the vent and block it. Subsequently, with ongoing eruption, the pressure buildup results in intense ejection of coarser-grained material. The juvenile pyroclasts in the Finca la Nava maar show features consistent with magmatic fragmentation (rounded fluidal shapes, coating of moderately vesicular magma onto xenolithic material) but also relatively fine grain size distributions (consistent with phreatomagmatic fragmentation). Although we cannot constrain the fragmentation processes in detail, we find indications that fragmentation started probably relatively shallow (as recorded by the high abundance of quartzitic fragments) and that both magmatic and phreatomagmatic fragmentation may have played important roles in this eruption. In particular, the finer-grained lower outcrop points to a phreatomagmatic-dominated fragmentation, which could be triggered when the uprising magma got in contact with a possibly water-bearing horizon in the slate-rich layer. With time, the eruption dried out and changed to a more magmatic fragmentation mode.

Acknowledgments We gratefully acknowledge the detailed comments of Károly Németh and an anonymous reviewer, which helped to improve the quality of the paper. We also thank Peter Ulmer and Daniel Weidendorfer for discussions about magmatic and volcanological processes at the Finca la Nava maar and elsewhere.

\section{References}

Allen SR, Smith IE (1994) Eruption styles and volcanic hazard in the Auckland Volcanic Field, New Zealand. Geosci Rep Shizuoka Univ 20:5-14

Ancochea E (2004) La región volcánica del Campo de Calatrava. In: Vera JA (ed) Geológia de España. Sociedad Geológia de España and Instituto de Geológia y Minero de España, Madrid, pp 676-677

Auer A, Martin U, Nemeth K (2007) The Fekete-hegy (Balaton Highland Hungary)"soft-substrate" and "hard-substrate" maar volcanoes in an aligned volcanic complex-Implications for vent geometry, subsurface stratigraphy and the palaeoenvironmental setting. J Volcanol Geotherm Res 159:225-245

Bailey K, Garson M, Kearns S, Velasco AP (2005) Carbonate volcanism in Calatrava, central Spain: a report on the initial findings. Mineral Mag 69:907-915

Bas MJL (1989) Nephelinitic and basanitic rocks. J Petrol 30:1299-1312

Bas MJL, Maitre RWL, Streckeisen A, Zanettin B (1986) A chemical classification of volcanic rocks based on the total alkali-silica diagram. J Petrol 27:745-750

Berghuijs JF, Mattsson HB (2013) Magma ascent, fragmentation and depositional characteristics of "dry" maar volcanoes: similarities with vent-facies kimberlite deposits. J Volcanol Geotherm Res 252:53-72

Bianchini G, Beccaluva L, Bonadiman C, Nowell GM, Pearson DG, Siena F, Wilson M (2010) Mantle metasomatism by melts of HIMU piclogite components: new insights from Fe-lherzolite xenoliths (Calatrava Volcanic District, central Spain). Geol Soc London Spec Pub 337:107-124

Blott SJ, Pye K (2001) Gradistat: a grain-size distribution and statistics package for the analysis of unconsolidated sediments. Earth Surf Proc Landf 26:1237-1248

Blundy J, Cashman K (2005) Rapid decompression-driven crystallization recorded by melt inclusions from Mount St. Helens volcano. Geology 33:793-796

Brenna M, Cronin SJ, Németh K, Smith IEM, Sohn YK (2011) The influence of magma plumbing complexity on monogenetic eruptions, Jeju Island, Korea. Terra Nova 23:70-75

Brooker RA, Kohn SC, Holloway JR, McMillan PF (2001) Structural controls on the solubility of $\mathrm{CO} 2$ in silicate melts: part I: bulk solubility data. Chem Geology 174:225-239

Brown RJ, Tait M, Field M, Sparks RSJ (2009) Geology of a complex kimberlite pipe (K2 pipe, Venetia Mine, South Africa): insights into conduit processes during explosive ultrabasic eruptions. Bull Volcanol 71:95-112

Büttner R, Dellino P, La Volpe L, Lorenz V, Zimanowski B (2002) Thermohydraulic explosions in phreatomagmatic eruptions as evidenced by the comparison between pyroclasts and products from Molten Fuel Coolant Interaction experiments. J Geophys Res 107:2277-2290

Carracedo Sánchez M, Sarrionandia F, Arostegui J, Larrondo E, Ibarguchi JIG (2009) Development of spheroidal composite bombs by welding of juvenile spinning and isotropic droplets inside a mafic eruption column. J Volcanol Geotherm Res 186:265-279

Cas R, Porritt L, Pittari A, Hayman P (2008) A new approach to kimberlite facies terminology using a revised general approach to the nomenclature of all volcanic rocks and deposits: descriptive to genetic. J Volcanol Geotherm Res 174:226-240

Cebriá JM (1992) Geoquímica de las rocas basálticas y leucititas de la región volcánica de Campo de Calatrava, España. Ph.D Thesis, Complutense University of Madrid, $341 \mathrm{p}$

Cebriá JM, López-Ruiz J (1995) Alkali basalts and leucitites in an extensional intracontinental plate setting: the late Cenozoic Calatrava Volcanic Province (central Spain). Lithos 35:27-46 
Cebriá J-M, López-Ruiz J (1996) A refined method for trace element modelling of nonmodal batch partial melting processes: the Cenozoic continental volcanism of Calatrava, central Spain. Geochim Cosmochim Acta 60:1355-1366

Clement C (1982) A comparative geological study of some major kimberlite pipes in the Northern Cape and Orange Free State. Ph.D Thesis, University of Cape Town, South Africa, $432 \mathrm{p}$

Cole PD, Guest JE, Duncan AM, Pacheco JM (2001) Capelinhos 1957-1958, Faial, Azores: deposits formed by an emergent surtseyan eruption. Bull Volcanol 63:204-220

Dawson JB, Smith JV (1988) Metasomatised and veined upper-mantle xenoliths from Pello Hill, Tanzania: evidence for anomalously-light mantle beneath the Tanzanian sector of the East African Rift Valley. Contrib Mineral Petrol 100:510-527

Dellino P, Isaia R, Volpe LL, Orsi G (2001) Statistical analysis of textural data from complex pyroclastic sequences: implications for fragmentation processes of the Agnano-Monte Spina Tephra (4.1 ka), Phlegraean Fields, southern Italy. Bull Volcanol 63:443-461

Delpit S, Ross P-S, Hearn BC Jr (2014) Deep-bedded ultramafic diatremes in the Missouri River Breaks volcanic field, Montana, USA: $1 \mathrm{~km}$ of syn-eruptive subsidence. Bull Volcanol 76:1-22

Demouchy S, Jacobsen SD, Gaillard F, Stern CR (2006) Rapid magma ascent recorded by water diffusion profiles in mantle olivine. Geology 34:429-432

Dufek J, Manga M (2008) In situ production of ash in pyroclastic flows. J Geophys Res Solid Earth 113:B09207

Field M, Scott Smith B (1998) Contrasting geology and near-surface emplacement of kimberlite pipes in Southern Africa and Canada. In: Gurney J (ed) 7th International Kimberlite Conference Extended Abstracts, pp 214-237

Fisher RV, Schmincke H-U (1984) Pyroclastic rocks. Springer, Berlin $472 \mathrm{p}$

Furman T, Graham D (1999) Erosion of lithospheric mantle beneath the East African Rift system: geochemical evidence from the Kivu volcanic province. Lithos 48:237-262

Geshi N, Németh K, Oikawa T (2011) Growth of phreatomagmatic explosion craters: a model inferred from Suoana crater in Miyakejima Volcano, Japan. J Volcanol Geotherm Res 201:30-38

Graettinger A, Valentine G, Sonder I, Ross PS, White J, Taddeucci J (2014) Maar-diatreme geometry and deposits: subsurface blast experiments with variable explosion depth. Geochem Geophys Geosys 15:740-764

Green DH, Edgar AD, Beasley P, Kiss E, Ware NG (1974) Upper mantle source for some hawaiites, mugearites and benmoreites. Contrib Mineral Petrol 48:33-43

Guillong M, Meier D, Allan M, Heinrich C, Yardley B (2008) SILLS: a MATLAB-based program for the reduction of laser ablation ICP-MS data of homogeneous materials and inclusions. Mineral Assoc Can Short Course Ser 40:328-333

Günther D, Frischknecht R, Heinrich CA, Kahlert H-J (1997) Capabilities of an argon fluoride $193 \mathrm{~nm}$ excimer laser for laser ablation inductively coupled plasma mass spectrometry microanalysis of geological materials. J Anal At Spectrom 12:939-944

Hardarson BS, Fitton JG (1991) Increased mantle melting beneath Snaefellsjökull volcano during Late Pleistocene deglaciation. Nature 353:62-64

Houghton B, Smith R (1993) Recycling of magmatic clasts during explosive eruptions: estimating the true juvenile content of phreatomagmatic volcanic deposits. Bull Volcanol 55:414-420

Houghton BF, Wilson CJN, Smith IEM (1999) Shallow-seated controls on styles of explosive basaltic volcanism: a case study from New Zealand. J Volcanol Geotherm Res 91:97-120

Inman DL (1952) Measures of describing the size distribution of sediments. J Sediment Res 22:125-145
Jordan SC, Cas RAF, Hayman PC (2013) The origin of a large $(<3 \mathrm{~km})$ maar volcano by coalescence of multiple shallow craters: lake Purrumbete maar, southeastern Australia. J Volcanol Geotherm Res 254:5-22

Jordan SC, Jowitt SM, Cas RAF (2014) Origin of temporal-compositional variations during the eruption of Lake Purrumbete Maar, Newer Volcanics Province, southeastern Australia. Bull Volcanol 77:1-15

Kienle J, Kyle PR, Self S, Motyka RJ, Lorenz V (1980) Ukinrek Maars, Alaska, I. April 1977 eruption sequence, petrology and tectonic setting. J Volcanol Geotherm Res 7:11-37

Klügel A, Hansteen TH, Schmincke HU (1997) Rates of magma ascent and depths of magma reservoirs beneath La Palma (Canary Islands). Terra Nova 9:117-121

Kueppers U, Putz C, Spieler O, Dingwell DB (2012) Abrasion in pyroclastic density currents: insights from tumbling experiments. Phys Chem Earth 45-46:33-39

Kurszlaukis S, Fulop A (2013) Factors controlling the internal facies architecture of maar-diatreme volcanoes. Bull Volcanol 75:1-12

Kurszlaukis S, Büttner R, Zimanowski B, Lorenz V (1998) On the first experimental phreatomagmatic explosion of a kimberlite melt. J Volcanol Geotherm Res 80:323-326

Lange RL, Carmichael ISE (1990) Thermodynamic properties of silicate liquids with emphasis on density, thermal expansion and compressibility. Rev Mineral Geochem 24:25-64

LaTourrette T, Hervig RL, Holloway JR (1995) Trace element partitioning between amphibole, phlogopite, and basanite melt. Earth Planet Sci Lett 135:13-30

Lee WJ, Huang WL, Wyllie P (2000) Melts in the mantle modeled in the system $\mathrm{CaO}-\mathrm{MgO}-\mathrm{SiO}_{2}-\mathrm{CO}_{2}$ at $2.7 \mathrm{GPa}$. Contrib Miner Petrol 138:199-213

Lefebvre N, Kurszlaukis S (2008) Contrasting eruption styles of the 147 Kimberlite, Fort à la Corne, Saskatchewan, Canada. J Volcanol Geotherm Res 174:171-185

Lefebvre N, White J, Kjarsgaard B (2013) Unbedded diatreme deposits reveal maar-diatreme-forming eruptive processes: standing Rocks West, Hopi Buttes, Navajo Nation, USA. Bull Volcanol 75:1-17

Longerich HP, Jackson SE, Günther D (1996) Inter-laboratory note. Laser ablation inductively coupled plasma mass spectrometric transient signal data acquisition and analyte concentration calculation. J Anal Atomic Spectrom 11:899-904

López-Ruiz J, Cebriá JM, Doblas M, Oyarzun R, Hoyos M, Martín C (1993) Cenozoic intra-plate volcanism related to extensional tectonics at Calatrava, central Iberia. J Geol Soc 150:915-922

Lorenz V (1971) An investigation of volcanic depressions, part IV. Origin of hole-in-the-ground, a maar in central oregongeological, geophysical, and energy investigations. NASA (National Aeronautics and Space Administration), Houston, Texas, Progress Report NGR-38-003-012

Lorenz V (1973) On the formation of maars. Bull Volcanol 37:183-204

Lorenz V (1974) Vesiculated tuffs and associated features. Sedimentology 21:273-291

Lorenz V (1975) Formation of phreatomagmatic maar-diatreme volcanoes and its relevance to kimberlite diatremes. Phys Chem Earth 9:17-27

Lorenz V (1986) On the growth of maars and diatremes and its relevance to the formation of tuff rings. Bull Volcanol 48:265-274

Lorenz V (2003) Maar-diatreme volcanoes, their formation, and their setting in hard-rock or soft-rock environments. Geolines $15: 72-83$

Lorenz V (2007) Syn-and posteruptive hazards of maar-diatreme volcanoes. J Volcanol Geotherm Res 159:285-312

Lorenz V, Kurszlaukis S (2007) Root zone processes in the phreatomagmatic pipe emplacement model and consequences for the 
evolution of maar-diatreme volcanoes. J Volcanol Geotherm Res 159:4-32

MacDonald R, Rogers N, Fitton J, Black S, Smith M (2001) Plumelithosphere interactions in the generation of the basalts of the Kenya Rift, East Africa. J Petrol 42:877-900

Mana S et al (2012) Geochronology and geochemistry of the Essimingor volcano: melting of metasomatized lithospheric mantle beneath the North Tanzanian Divergence zone (East African Rift). Lithos 155:310-325

Martín-Serrano A et al (2009) Morphotectonic setting of maar lakes in the Campo de Calatrava Volcanic Field (Central Spain, SW Europe). Sediment Geol 222:52-63

Mattsson HB (2012) Rapid magma ascent and short eruption durations in the Lake Natron-Engaruka monogenetic volcanic field (Tanzania): a case study of the olivine melilititic Pello Hill scoria cone. J Volcanol Geotherm Res 247-248:16-25

Mattsson HB, Tripoli BA (2011) Depositional characteristics and volcanic landforms in the Lake Natron-Engaruka monogenetic field, northern Tanzania. J Volcanol Geotherm Res 203:23-34

Mattsson HB, Nandedkar RH, Ulmer P (2013) Petrogenesis of the melilititic and nephelinitic rock suites in the Lake NatronEngaruka monogenetic volcanic field, northern Tanzania. Lithos 179:175-192

McBirney AR (1963) Conductivity variations and terrestrial heat-flow distribution. J Geophys Res 68:6323-6329

Mcdonough WF, Sun SS (1995) The composition of the Earth. Chem Geol 120:223-253

McGee LE, Millet M-A, Smith IEM, Németh K, Lindsay JM (2012) The inception and progression of melting in a monogenetic eruption: Motukorea Volcano, the Auckland Volcanic Field, New Zealand. Lithos 155:360-374

Németh K (2010) Monogenetic volcanic fields: origin, sedimentary record, and relationship with polygenetic volcanism. Geol Soc Am Spec Pap 470:43-66

Németh K, Martin U, Harangi S (2001) Miocene phreatomagmatic volcanism at Tihany (Pannonian Basin, Hungary). J Volcanol Geotherm Res 111:111-135

Nixon PH (1995) The morphology and nature of primary diamondiferous occurrences. J Geochem Explor 53:41-71

Ort MH, Carrasco-Núñez G (2009) Lateral vent migration during phreatomagmatic and magmatic eruptions at Tecuitlapa Maar, east-central Mexico. J Volcanol Geotherm Res 181:67-77

Ross P-S, White JDL (2012) Quantification of vesicle characteristics in some diatreme-filling deposits, and the explosivity levels of magma-water interactions within diatremes. J Volcanol Geotherm Res 245-246:55-67

Ross P-S, Delpit S, Haller MJ, Németh K, Corbella H (2011) Influence of the substrate on maar-diatreme volcanoes-an example of a mixed setting from the Pali Aike volcanic field, Argentina. J Volcanol Geotherm Res 201:253-271

Self S, Kienle J, Huot J-P (1980) Ukinrek Maars, Alaska, II. Deposits and formation of the 1977 craters. J Volcanol Geotherm Res 7:39-65

Sohn YK, Park KH (2005) Composite tuff ring/cone complexes in Jeju Island, Korea: possible consequences of substrate collapse and vent migration. J Volcanol Geotherm Res 141:157-175

Solgevik H, Mattsson HB, Hermelin O (2007) Growth of an emergent tuff cone: fragmentation and depositional processes recorded in the Capelas tuff cone, São Miguel, Azores. J Volcanol Geotherm Res 159:246-266

Sparks RSJ, Baker L, Brown RJ, Field M, Schumacher J, Stripp G, Walters A (2006) Dynamical constraints on kimberlite volcanism. J Volcanol Geotherm Res 155:18-48
Spera FJ (1984) Carbon dioxide in petrogenesis III: role of volatiles in the ascent of alkaline magma with special reference to xenolith-bearing mafic lavas. Contrib Mineral Petrol 88:217-232

Spera FJ, Bergman SC (1980) Carbon Dioxide in igneous petrogenesis: I. Aspects of the dissolution of $\mathrm{CO}_{2}$ in silicate liquids. Contrib Mineral Petrol 74:55-66

Stoppa F (1996) The San Venanzo maar and tuff ring, Umbria, Italy: eruptive behaviour of a carbonatite-melilitite volcano. Bull Volcanol 57:563-577

Stoppa F, Rosatelli G, Schiazza M, Tranquilli A (2012) Hydrovolcanic vs magmatic processes in forming maars and associated pyroclasts: the Calatrava-Spain-case history. In: Stoppa F (ed) Updates in volcanology-a comprehensive approach to volcanological problems. InTech, Rijeka, pp 3-26

Stovall W, Houghton BF, Gonnermann H, Fagents SA, Swanson DA (2011) Eruption dynamics of Hawaiian-style fountains: the case study of episode 1 of the Kîlauea Iki 1959 eruption. Bull Volcanol 73:511-529

Suiting I, Schmincke H-U (2009) Internal vs. external forcing in shallow marine diatreme formation: a case study from the Iblean Mountains (SE-Sicily, Central Mediterranean). J Volcanol Geotherm Res 186:361-378

Suiting I, Schmincke H-U (2012) Iblean diatremes 3: volcanic processes on a Miocene carbonate platform (Iblean Mountains, SE-Sicily): a comparison of deep vs. shallow marine eruptive processes. Bull Volcanol 74:207-230

Valentine GA, White JDL (2012) Revised conceptual model for maardiatremes: subsurface processes, energetics, and eruptive products. Geology 40:1111-1114

Valentine GA, Graettinger AH, Sonder I (2014) Explosion depths for phreatomagmatic eruptions. Geophys Res Lett 41:3045-3051

Villaseca C, Ancochea E, Orejana D, Jeffries TE (2010) Composition and evolution of the lithospheric mantle in central Spain: inferences from peridotite xenoliths from the Cenozoic Calatrava volcanic field. Geol Soc London Spec Pub 337:125-151

Walker GPL (1971) Grain size characteristics of pyroclastic deposits. J Geol 79:696-714

Walker GP (1981) Generation and dispersal of fine ash and dust by volcanic eruptions. J Volcanol Geotherm Res 11:81-92

Walker GPL (1993) Basaltic-volcano systems. Geol Soc London Spec Pub 76:3-38

White JDL (1996) Impure coolants and interaction dynamics of phreatomagmatic eruptions. J Volcanol Geotherm Res 74:155-170

White JDL, Houghton BF (2006) Primary volcaniclastic rocks. Geology 34:677-680

White JDL, Ross PS (2011) Maar-diatreme volcanoes: a review. J Volcanol Geotherm Res 201:1-29

Wilson L, Head JW III (2007) An integrated model of kimberlite ascent and eruption. Nature 447:53-57

Wohletz KH (1983) Mechanisms of hydrovolcanic pyroclast formation: grain-size, scanning electron microscopy, and experimental studies. J Volcanol Geotherm Res 17:31-63

Wohletz K, Heiken G (1992) Volcanology and geothermal energy. University of California Press, Berkeley $432 \mathrm{p}$

Wohletz K, Zimanowski B (2000) Physics of phreatomagmatism, part I: explosion physics. Terra Nostra 6:515-523

Wyllie PJ, Huang W-L (1976) Carbonation and melting reactions in the system $\mathrm{CaO}-\mathrm{MgO}-\mathrm{SiO} 2-\mathrm{CO} 2$ at mantle pressures with geophysical and petrological applications. Contrib Mineral Petrol 54:79-107

Zimanowski B, Fröhlich G, Lorenz V (1991) Quantitative experiments on phreatomagmatic explosions. J Volcanol Geotherm Res 48:341-358 